\title{
Permeation, regulation and control of expression of TRP channels by trace metal ions
}

\author{
Alexandre Bouron • Kirill Kiselyov • \\ Johannes Oberwinkler
}

Received: 15 April 2014 /Revised: 10 July 2014 / Accepted: 13 July 2014 / Published online: 10 August 2014

(C) The Author(s) 2014. This article is published with open access at Springerlink.com

\begin{abstract}
Transient receptor potential (TRP) channels form a diverse family of cation channels comprising 28 members in mammals. Although some TRP proteins can only be found on intracellular membranes, most of the TRP protein isoforms reach the plasma membrane where they form ion channels and control a wide number of biological processes. There, their involvement in the transport of cations such as calcium and sodium has been well documented. However, a growing number of studies have started to expand our understanding of these proteins by showing that they also transport other biologically relevant metal ions like zinc, magnesium, manganese and cobalt. In addition to this newly recognized property, the activity and expression of TRP channels can be regulated by metal ions like magnesium, gadolinium, lanthanum or cisplatin. The aim of this review is to highlight the complex relationship between metal ions and TRP channels.
\end{abstract}

Keywords TRPA channels · TRPC channels · TRPM channels · TRPV channels · TRPP channels .

\footnotetext{
A. Bouron $(\bowtie)$

CNRS, 38054 Grenoble, France

e-mail: alexandre.bouron@cea.fr

A. Bouron

CEA, IRTSV, 38054 Grenoble, France

A. Bouron

Université Joseph Fouriers, 38054 Grenoble, France

K. Kiselyov

Department of Biological Sciences, University of Pittsburgh, Pittsburgh, PA 15260, USA

J. Oberwinkler $(\bowtie)$

Institut für Physiologie und Pathophysiologie, Philipps-Universität

Marburg, 35037 Marburg, Germany

e-mail: johannes.oberwinkler@uni-marburg.de
}

TRPML channels $\cdot$ Channel regulation · Transition metals · Zinc Cadmium · Copper · Magnesium · Nickel · Iron · Lead . Barium $\cdot$ Strontium $\cdot$ Manganese $\cdot$ Lanthanum $\cdot$ Gadolinium

\section{Introduction}

Some trace metals like zinc $\left(\mathrm{Zn}^{2+}\right)$, iron $\left(\mathrm{Fe}^{2+} / \mathrm{Fe}^{3+}\right)$ or copper $\left(\mathrm{Cu}^{+} / \mathrm{Cu}^{2+}\right)$ are involved in a wide diversity of biological processes. Other metal ions like cadmium $\left(\mathrm{Cd}^{2+}\right)$ or lead $\left(\mathrm{Pb}^{2+}\right)$ have only toxic properties, at least in vertebrate cells. The molecular mechanisms by which these cations enter into cells are still not fully understood. Among the various actors participating in the uptake of trace metal ions, ion channels represent an important class of metal-transporting proteins as they permit the import (or export) of ions moving according to their electrochemical gradients. Trace metal ions are commonly described as potent blockers of ion channels, but in fact, they exert more subtle actions on membrane conductances. When considering ion channels, four types of responses have been described when trace metal ions are applied extracellularly: (i) blockade, (ii) modulation, (iii) activation of ion channels and, in some instances, (iv) permeation through the channels [31, 44, 97, 98]. Even though permeation is not as well documented as the other three processes, L-type voltagegated calcium $\left(\mathrm{Ca}^{2+}\right)$ channels and ionotropic glutamate channels (AMPA and NMDA channels) are probably the bestknown metal-conducting channels, being permeable to a wide variety of cations such as ferrous iron $\left(\mathrm{Fe}^{2+}\right), \mathrm{Cd}^{2+}$ and $\mathrm{Zn}^{2+}$ $[16,57,65,127,161]$. Some transient receptor potential (TRP) channels have been shown to be permeable to trace metal ions, and it has been demonstrated in some cases that TRP channels are important for the physiological uptake of trace metal ions. In mammals, the TRP superfamily is subdivided into six families named TRPA, TRPC, TRPM, TRPML, TRPP and TRPV, each family comprising up to 
eight members [154, 171, 212]. With the exception of TRPM4 and TRPM5, which are monovalent-selective cation channels $[72,110]$, TRP channels conduct $\mathrm{Ca}^{2+}$. Most of them are located in the plasma membrane, but some are found both in the plasma membrane and in intracellular membranes (e.g. TRPM1, TRPM2, TRPM7, TRPM8, TRPC3, TRPV1 and TRPV4) and still others are exclusively found on intracellular membranes (e.g. TRPML channels; reviewed in [41]). The main aim of this review is to summarize recent studies showing that TRP channels can transport trace metal ions into the cytosolic compartment. In order to keep this review focussed, we will not discuss the transport and the regulatory effects of $\mathrm{Ca}^{2+}$ ions on TRP channels. In addition, we will only briefly summarize the transport of $\mathrm{Zn}^{2+}$ ions by TRP channels, as this topic has recently been covered [16]. This review also highlights another interesting characteristic of metal ions that has come into focus recently: their ability to regulate the expression of some TRP channels.

\section{Transport of metal ions through TRP channels}

Transport of metal ions through TRPA channels

TRPA1 is the only member of the family of TRPA channels in mammals. Its function has mainly been studied in dorsal root ganglia (DRG) where TRPA1 is found in a subset of nociceptive neurons [11]. It can be activated by an enormous variety of noxious or irritant substances $[11,153]$ and has thus been identified to play important roles in acute and chronic, inflammatory pain [153]. The pore of TRPA1 is highly permeable to $\mathrm{Ca}^{2+}$ and, somewhat less, to magnesium $\left(\mathrm{Mg}^{2+}\right)$ [92]. This was also confirmed on the single-channel level, where it was additionally demonstrated that TRPA 1 channels conduct barium $\left(\mathrm{Ba}^{2+}\right)$ [14]. This is in agreement with an earlier report showing that extracellular $\mathrm{Ba}^{2+}$ potentiates TRPA1 channels similarly to $\mathrm{Ca}^{2+}$ ions, an effect that was thought to require permeation of these ions [227]. Furthermore, based on measurements with a $\mathrm{Zn}^{2+}$-selective fluorescent indicator, murine TRPA1 was found to be permeable to $\mathrm{Zn}^{2+}$ [77]. Importantly, the D915A mutation in the pore region of TRPA1 abolished $\mathrm{Zn}^{2+}$ permeability [227]. TRPA1 channels display a basal level of constitutive activity (like many other TRP channels, reviewed in [116]). In the presence of extracellular $\mathrm{Zn}^{2+}$, the basal activity of TRPA1 channels permits entry of $\mathrm{Zn}^{2+}$ ions. Once on the intracellular side, $\mathrm{Zn}^{2+}$ ions bind to sites located in both the C- and N-termini of TRPA1 and sensitize the channels effectively augmenting their activity (see section "Activation and potentiation of TRPA channels"). The injection of $\mathrm{Cd}^{2+}$ into the skin also elicits pain $[55,77]$. The mechanism proposed is very similar to the one for $\mathrm{Zn}^{2+}$ : $\mathrm{Cd}^{2+}$ ions also permeate TRPA 1 channels and then positively modulate their activity [136]. The effects of $\mathrm{Cd}^{2+}$ are also dependent on the aspartate in position 915, indicating that indeed, divalent permeation through TRPA1 is important [136]. The permeability of TRPA1 channels to trace metal ions may therefore have pathophysiological importance.

Transport of metal ions through TRPC channels

Canonical TRP (or TRPC) proteins represent a prominent class of the TRP superfamily. Like most TRP proteins, they form $\mathrm{Ca}^{2+}$-conducting channels allowing the entry of $\mathrm{Ca}^{2+}$ into the cytosol. Among the seven isoforms (TRPC1TRPC7), TRPC6 is the only TRPC channel known to transport physiologically relevant trace elements. Specifically, it allows the uptake of iron $\left(\mathrm{Fe}^{2+}\right.$ and $\left.\mathrm{Fe}^{3+}\right)$ and $\mathrm{Zn}^{2+}[50,143]$. TRPC6 is commonly described as a second messengeroperated channel that can be activated by diacylglycerol [37, 73]. In PC12 cells, TRPC6 channels permit entry of iron ( $\mathrm{Fe}^{2+}$ and $\mathrm{Fe}^{3+}$ ) independently of transferrin and its receptor [143]. PC12 is a pheochromocytoma cell line used as a model to study neuronal differentiation and ion channel expression [52]. When grown in the absence of the nerve growth factor (NGF), PC12 cells have a rounded shape and divide continuously. However, when treated with NGF, they form long and branched processes. Moreover, they become electrically excitable and exhibit properties similar to sympathetic neurons [52]. The NGF-induced morphological differentiation of PC12 cells is associated with a marked enhancement of the expression of TRPC6 [143, 201]. Transfection of HEK-293 cells with a plasmid expressing TRPC6 promotes the entry of $\mathrm{Fe}^{2+}$ or $\mathrm{Fe}^{3+}$ [143]. It is interesting to note that overexpression of TRPC channels can influence the $\mathrm{Ca}^{2+}$ and $\mathrm{Zn}^{2+}$ load of the host cells. For instance, overexpressing TRPC 3 channels in HEK-293 cells reduces the size of their intracellular $\mathrm{Ca}^{2+}$ pools [122]. On the other hand, the overexpression of TRPC6 channels in HEK-293 cells provokes an intracellular accumulation of $\mathrm{Zn}^{2+}$ (and reduces the copper content) [24, 50]. TRPC6 overexpressing HEK-293 cells is more sensitive to oxidative insults and has larger pools of mobilizable $\mathrm{Zn}^{2+}$. Live cell-imaging experiments and whole-cell patch-clamp recordings show that TRPC6 channels, but not TRPC 3 channels, can transport $\mathrm{Zn}^{2+}$ ions and this TRPC6-dependent $\mathrm{Zn}^{2+}$ uptake regulates the size of the internal pools of mobilizable $\mathrm{Zn}^{2+}$ in neurons [50]. Whether additional TRPC channels can facilitate the uptake of $\mathrm{Zn}^{2+}$ has not been reported so far.

For many TRPC channels, permeability for $\mathrm{Ba}^{2+}$ and manganese $\left(\mathrm{Mn}^{2+}\right)$ has been demonstrated in imaging experiments using fluorescent indicator molecules. $\mathrm{Mn}^{2+}$, for instance, quenches Fura-2 fluorescence, which can conveniently be monitored at $360 \mathrm{~nm}$, the isosbestic wavelength of Fura-2. It has thus been demonstrated that TRPC3, TRPC4, TRPC5, TRPC6 and TRPC 7 channels are permeable for $\mathrm{Mn}^{2+}[38,73$, $160,245] . \mathrm{Ba}^{2+}$ entry can also be monitored with Fura-2, and 
this has been used to show that TRPC3, TRPC6 and TRPC7 channels conduct $\mathrm{Ba}^{2+}$ ions $[120,129,211]$.

\section{Transport of metal ions through TRPM channels}

The mammalian subfamily of TRPM channel proteins comprises eight members that are, based on their primary amino acid sequence, broadly divided into two groups: TRPM1, TRPM3, TRPM6 and TRPM7 forming one group, and TRPM2, TRPM8, TRPM4 and TRPM5 forming the second group. The first TRP channel investigated with respect to trace metal permeation was TRPM7 [137, 144]. It displays a high permeability for $\mathrm{Mg}^{2+}$ ions, which once they accumulate intracellularly, also regulate the channel activity (see section "Inhibition of TRP channels by magnesium ions"). Therefore, currents through TRPM7 channels have also been named "magnesium nucleotide-regulated metal currents" (MagNuM [144]) or "magnesium-inhibited current" (MIC [168]). Subsequent studies showed that TRPM7 channels are permeable to a wide variety of divalent cations, including physiologically important trace metal ions, such as cobalt $\left(\mathrm{Co}^{2+}\right), \mathrm{Mn}^{2+}$ and most importantly $\mathrm{Zn}^{2+}$, which seems to permeate TRPM7 channels particularly well $[118,137,204]$. In addition, potentially toxic divalent cations, such as nickel $\left(\mathrm{Ni}^{2+}\right)$, strontium $\left(\mathrm{Sr}^{2+}\right)$ and $\mathrm{Cd}^{2+}$, permeate TRPM7 channels. The permeation of TRPM7 by these divalent ions has been well established under experimentally simplified, so-called bi-ionic, conditions. This, however, does not necessarily mean that TRPM7 channels participate in the cellular uptake of all these divalent ions to a meaningful extent under physiological conditions. In the presence of physiological concentrations of $\mathrm{Ca}^{2+}$, other divalent ions may not be able to compete for access to the channel pore. For $\mathrm{Mg}^{2+}$, however, a number of publications demonstrated that cells without TRPM7 channels or with nonfunctional TRPM7 channels have a substantially diminished $\mathrm{Mg}^{2+}$ content and therefore stop proliferating [178, 183] (but see also [86]). Since this phenotype can be rescued by supplying high amounts of extracellular $\mathrm{Mg}^{2+}$, it appears that the function of TRPM7 proteins as cellular $\mathrm{Mg}^{2+}$ uptake channels is of high physiological relevance. Similarly, it has been argued that TRPM7 channels provide an important pathway for neuronal $\mathrm{Zn}^{2+}$ uptake and subsequent cell death in the pathophysiological context of ischemic stroke [80]. However, since previous studies have also implicated TRPM7 in the $\mathrm{Ca}^{2+}$-mediated neuronal injury after ischemic stroke [1], further work will be needed to clarify which of the two proposed cations flowing through TRPM7 is (more) responsible for the pathological consequences of stroke. In addition, TRPM7 channels have been used experimentally to increase $\mathrm{Zn}^{2+}$ uptake in HEK293 cells [76]. Finally, some pharmacological evidence has been put forward that TRPM7 channels are important in cellular $\mathrm{Cd}^{2+}$ and $\mathrm{Mn}^{2+}$ uptake $[62,126]$. Altogether, the available data strengthen the hypothesis that
TRPM7 channels provide a pathway for trace metal ion uptake also in vivo, under physiological and pathophysiological conditions.

TRPM6 is the closest homologue of TRPM7, and the two proteins are structurally similar. For example, they share the highly unusual feature of a functional kinase domain attached to the C-terminal of the protein [177]. While TRPM7 seems to be ubiquitously expressed $[165,176]$, TRPM6 proteins are found mainly in the intestine and in kidneys $[182,224]$. Human infants with loss-of-function mutations in TRPM6 develop severe hypomagnesemia with secondary hypocalcemia (HSH) [182, 224], indicating that TRPM6 is important for $\mathrm{Mg}^{2+}$ (re-) absorption in the intestine and in kidneys. Biophysical studies indicated that ion channels formed from TRPM6 proteins, much like TRPM7 channels, are also permeable to many other divalent cations, like $\mathrm{Ba}^{2+}, \mathrm{Ni}^{2+}, \mathrm{Cd}^{2+}$, $\mathrm{Sr}^{2+}, \mathrm{Mn}^{2+}$ and $\mathrm{Zn}^{2+}[118,204,217]$. However, for undetermined reasons, the reported permeability sequences differ between these studies (see Table 1). One complicating factor is the propensity of TRPM6 and TRPM7 proteins to form heteromultimeric complexes [27, 118]. Homomeric channels formed from only TRPM7 or TRPM6 proteins and heteromultimeric channels formed from both proteins can be distinguished from each other on biophysical and pharmacological grounds $[117,118]$. With respect to the topic of this review, the differential amplitude of currents carried by $\mathrm{Ni}^{2+}$ is of special interest [118].

Some mechanistic insight has been gained on the permeation of divalent cations by TRPM7 and TRPM6. On removal of divalent cations, channels formed by TRPM7 and TRPM6 proteins support large monovalent inward currents $[85,95$, 103]. These monovalent inward currents are reduced by adding divalent cations in a dose-dependent manner, arguing that the classical concept of a permeant blocking ion that binds inside the pore ("sticky pore concept", [64]) also applies to divalent cations permeating TRPM6 and TRPM7 channels. A number of additional observations support this notion. First, anomalous mole fraction behaviour could be demonstrated for TRPM7 and TRPM6 channels $[118,144]$. Second, increasing the extracellular proton concentration reduces the apparent affinity of the channel for divalent cations, arguing for a competition between protons and divalent cations for the same binding site [85]. Finally, mutating crucial glutamate residues to glutamine in both TRPM6 and TRPM7, strongly reduces divalent ion permeability and affinity of divalent binding to the pore $[117,131]$. A consequence of the sticky pore concept is that divalent cations compete with each other for permeation through the channel. Therefore, it is unclear whether and how much a given species of trace metal ions (that typically are present only in very low concentrations) can compete with the physiologically much more abundant ions $\mathrm{Ca}^{2+}$ and $\mathrm{Mg}^{2+}$ for access to the channels. As mentioned above, some data on this 
Table 1 Rank orders of inward current amplitudes and relative permeability ratios of TRP channels to metal ions in comparison to other divalent cations

\begin{tabular}{|c|c|c|c|}
\hline Channel & $\begin{array}{l}\text { Permeable metal ions and rank } \\
\text { order of inward current amplitudes }\end{array}$ & $\begin{array}{l}\text { Rank order of relative } \\
\text { permeability ratios }^{\mathrm{a}}\end{array}$ & References \\
\hline TRPA1 & $\mathrm{Ca}^{2+}, \mathrm{Mg}^{2+}, \mathrm{Ba}^{2+}, \mathrm{Zn}^{2+}, \mathrm{Cd}^{2+}, \mathrm{Co}^{2+}$ & n.d. & {$[14,77,92]$} \\
\hline TRPC3 & $\mathrm{Ca}^{2+}, \mathrm{Ba}^{2+}, \mathrm{Mn}^{2+}$ & n.d. & {$[73,129,245]$} \\
\hline TRPC4/5 & $\mathrm{Ca}^{2+}, \mathrm{Mn}^{2+}$ & n.d. & {$[73]$} \\
\hline TRPC6 & $\mathrm{Ca}^{2+}, \mathrm{Ba}^{2+}, \mathrm{Mn}^{2+}, \mathrm{Zn}^{2+}, \mathrm{Fe}^{2+} / \mathrm{Fe}^{3+}$ & n.d. & {$[38,50,73,120,143,160]$} \\
\hline TRPC7 & $\mathrm{Ca}^{2+}, \mathrm{Ba}^{2+}, \mathrm{Mn}^{2+}$ & n.d. & {$[120]$} \\
\hline TRPM1 & $\mathrm{Ca}^{2+}>\mathrm{Ba}^{2+}>\mathrm{Mg}^{2+}>\mathrm{Ni}^{2+}$ & $\mathrm{Ba}^{2+}>\mathrm{Ca}^{2+}>\mathrm{Mg}^{2+}>\mathrm{Ni}^{2+}$ & [108] \\
\hline TRPM2 & $\mathrm{Ca}^{2+}, \mathrm{Mg}^{2+}, \mathrm{Ba}^{2+}, \mathrm{Mn}^{2+}$ & $\mathrm{Ca}^{2+} \approx \mathrm{Mg}^{2+} \approx \mathrm{Ba}^{2+}$ & $\begin{array}{l}{[60,105,131,167,203} \\
\quad 205,231]\end{array}$ \\
\hline TRPM $3 \alpha 2$ & $\mathrm{Ca}^{2+}>\mathrm{Zn}^{2+}>\mathrm{Mg}^{2+}>\mathrm{Ni}^{2+}$ & $\mathrm{Ni}^{2+}>\mathrm{Mg}^{2+}>\mathrm{Zn}^{2+} \approx \mathrm{Ca}^{2+}>\mathrm{Ba}^{2+}$ & [222] \\
\hline TRPM6 & $\begin{array}{l}\mathrm{Ba}^{2+}>\mathrm{Ni}^{2+}>\mathrm{Mg}^{2+}>\mathrm{Ca}^{2+} \\
\mathrm{Ba}^{2+}>\mathrm{Ni}^{2+}>\mathrm{Mg}^{2+}>\mathrm{Zn}^{2+} \sim \mathrm{Ca}^{2+} \\
\mathrm{Zn}^{2+}>\mathrm{Ba}^{2+}>\mathrm{Mg}^{2+} \sim \mathrm{Ca}^{2+}>\mathrm{Sr}^{2+}>\mathrm{Cd}^{2+}>\mathrm{Ni}^{2+}\end{array}$ & $\mathrm{Ni}^{2+}>\mathrm{Mg}^{2+}>\mathrm{Ca}^{2+}>\mathrm{Mg}^{2+}$ & $\begin{array}{l}{[217]} \\
{[204]} \\
{[118]}\end{array}$ \\
\hline TRPM7 & $\begin{array}{l}\mathrm{Zn}^{2+} \sim \mathrm{Ni}^{2+}>>\mathrm{Ba}^{2+}>\mathrm{Co}^{2+}>\mathrm{Mg}^{2+} \geq \mathrm{Mn}^{2+} \geq \mathrm{Sr}^{2+} \\
\geq \mathrm{Cd}^{2+} \geq \mathrm{Ca}^{2+} \\
\mathrm{Ba}^{2+}>\mathrm{Ni}^{2+}>\mathrm{Zn}^{2+}>\mathrm{Mg}^{2+}>\mathrm{Ca}^{2+} \\
\mathrm{Ni}^{2+}>\mathrm{Ba}^{2+} \approx \mathrm{Mg}^{2+} \approx \mathrm{Zn}^{2+} \approx \mathrm{Sr}^{2+}>\mathrm{Cd}^{2+}\end{array}$ & $\begin{array}{l}\mathrm{Ni}^{2+} \approx \mathrm{Co}^{2+} \approx \mathrm{Ca}^{2+}>\mathrm{Mn}^{2+}>\mathrm{Sr}^{2+} \\
\quad>\mathrm{Ba}^{2+} \approx \mathrm{Mg}^{2+}\end{array}$ & $\begin{array}{l}{[137]} \\
{[204]} \\
{[118]} \\
{[131]}\end{array}$ \\
\hline TRPM8 & $\begin{array}{l}\mathrm{Ca}^{2+}, \mathrm{Mg}^{2+}, \mathrm{Ba}^{2+}, \mathrm{Mn}^{2+} \\
\left.\mathrm{Ca}^{2+}>\mathrm{Sr}^{2+}=\mathrm{Ba}^{2+}>\mathrm{Mn}^{2+} \text { (in LNCaP cells }\right)\end{array}$ & $\mathrm{Ba}^{2+}>\mathrm{Ca}^{2+}>\mathrm{Mg}^{2+}$ & $\begin{array}{l}{[131,175]} \\
{[202]}\end{array}$ \\
\hline dTRPM & $\mathrm{Zn}^{2+}>\mathrm{Co}^{2+} \approx \mathrm{Mn}^{2+}>\mathrm{Ni}^{2+} \approx \mathrm{Ca}^{2+}>\mathrm{Ba}^{2+}$ & n.d. & [49] \\
\hline GON-2 & $\mathrm{Ca}^{2+}, \mathrm{Mg}^{2+}$ & n.d. & {$[199,232]$} \\
\hline GTL-1 & $\mathrm{Ca}^{2+}, \mathrm{Mg}^{2+}$ & n.d. & {$[199,232]$} \\
\hline TRPML1 & $\mathrm{Fe}^{2+}, \mathrm{Zn}^{2+}, \mathrm{Mn}^{2+}, \mathrm{Ca}^{2+}, \mathrm{Mg}^{2+}, \mathrm{Ni}^{2+}, \mathrm{Co}^{2+}, \mathrm{Cd}^{2+}$ & n.d. & {$[39,233]$} \\
\hline TRPML2 & $\mathrm{Fe}^{2+}$ & n.d. & [39] \\
\hline TRPML3 & $\mathrm{Ca}^{2+}, \mathrm{Sr}^{2+}, \mathrm{Ba}^{2+}, \mathrm{Mg}^{2+}$ & $\mathrm{Ca}^{2+}>\mathrm{Sr}^{2+}>\mathrm{Ba}^{2+}$ & {$[96,233]$} \\
\hline TRPP2 & $\mathrm{Ca}^{2+}, \mathrm{Mg}^{2+}, \mathrm{Ba}^{2+}$ & n.d. & {$[6,100]$} \\
\hline TRPP3 & $\begin{array}{l}\mathrm{Ca}^{2+}, \mathrm{Ba}^{2+}, \mathrm{Sr}^{2+}>\mathrm{Mg}^{2+} \\
\mathrm{Ca}^{2+}, \mathrm{Ba}^{2+}, \mathrm{Mg}^{2+}, \mathrm{Mn}^{2+}\end{array}$ & n.d. & $\begin{array}{l}{[23]} \\
{[197]}\end{array}$ \\
\hline TRPP3+PKD1L1 & $\mathrm{Ca}^{2+}, \mathrm{Ba}^{2+}$ & $\mathrm{Ca}^{2+} \approx \mathrm{Ba}^{2+}$ & [32] \\
\hline TRPP3+PKD1L3 & $\mathrm{Ca}^{2+}, \mathrm{Mg}^{2+}$ & n.d. & {$[79,240]$} \\
\hline TRPV1 & $\mathrm{Ca}^{2+}, \mathrm{Mg}^{2+}, \mathrm{Co}^{2+}$ & $\mathrm{Ca}^{2+}>\mathrm{Mg}^{2+}$ & {$[2,21,47,180]$} \\
\hline TRPV2 & $\mathrm{Ca}^{2+}, \mathrm{Mg}^{2+}$ & $\mathrm{Ca}^{2+}>\mathrm{Mg}^{2+}$ & [20] \\
\hline TRPV3 & $\mathrm{Ca}^{2+}, \mathrm{Sr}^{2+}$ & & [19] \\
\hline TRPV4 & $\mathrm{Ca}^{2+}, \mathrm{Mg}^{2+}, \mathrm{Sr}^{2+}, \mathrm{Mn}^{2+}$ & $\mathrm{Ca}^{2+} \approx \mathrm{Sr}^{2+}>\mathrm{Ba}^{2+}$ & {$[191,219,228]$} \\
\hline TRPV5 & $\begin{array}{l}\mathrm{Ca}^{2+}>\mathrm{Ba}^{2+}>\mathrm{Sr}^{2+}>\mathrm{Mn}^{2+} \\
\mathrm{Zn}^{2+}, \mathrm{Cd}^{2+}\end{array}$ & $\mathrm{Ca}^{2+}>\mathrm{Mn}^{2+}>\mathrm{Ba}^{2+} \approx \mathrm{Sr}^{2+}$ & 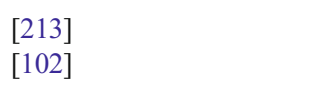 \\
\hline TRPV6 & $\begin{array}{l}\mathrm{Ca}^{2+}>\mathrm{Sr}^{2+}>\mathrm{Ba}^{2+}>\mathrm{Mn}^{2+} \\
\mathrm{Zn}^{2+}>\mathrm{Cd}^{2+}>\mathrm{Ca}^{2+} ; \mathrm{La}^{3+}, \mathrm{Gd}^{3+}\end{array}$ & $\mathrm{Ca}^{2+}>\mathrm{Sr}^{2+}>\mathrm{Ba}^{2+}>\mathrm{Mn}^{2+}$ & $\begin{array}{l}{[68,241]} \\
{[101]}\end{array}$ \\
\hline
\end{tabular}

${ }^{\text {a }}$ Relative permeabilities were estimated from measurements of reversal potentials under bi-ionic conditions. Note that the precise conditions under which the inward current amplitudes and relative permeabilities were determined vary widely between the different studies. Hence, only rank orders are given

question are available for TRPM7, but this is the exception rather than the rule. For the vast majority of TRP channels, it is unknown if and to what extent the permeability to trace metal ions results in influx of these ions under physiological conditions.

The closest homologues of TRPM6 and TRPM7 are TRPM1 and TRPM3, which can both be activated by the endogenous steroid pregnenolone sulphate [42, 108, 223]. While TRPM1 channels are indispensable for the signal transduction in retinal ON bipolar cells [138], TRPM3 channels have been implicated in insulin release from pancreatic $\beta$ cells and detection of noxious heat in cutaneous nociceptor neurons [189, 221, 223]. Given their high degree of homology, especially in the region of the primary sequence that is thought to form the ion-conducting pore, it was expected that those channels are also broadly permeable to divalent cations. The situation is more complex than this, however, because both TRPM1 and TRPM3 are subject to alternative splicing 
[46, 156-158]. One site of alternative splicing, conserved in TRPM1 and TRPM3, affects the pore-forming region of the proteins. For TRPM3 channels, this has been shown to lead to protein isoforms that have distinctly different permeability profiles (see Table 1). Channels with the short pore sequence (the isoform TRPM $3 \alpha 2$ was studied most) are highly permeable to a wide variety of divalent cations $\left(\mathrm{Ca}^{2+}, \mathrm{Mg}^{2+}, \mathrm{Zn}^{2+}\right.$, $\left.\mathrm{Mn}^{2+}, \mathrm{Ba}^{2+}, \mathrm{Ni}^{2+}\right)$, much like TRPM6 or TRPM7 channels, but with a different permeability sequence [157, 222]. The permeability to $\mathrm{Mn}^{2+}$ has been exploited in imaging experiments to quench Fura-2 [70]. On the contrary, TRPM3 channels with the long-pore sequence (named TRPM $3 \alpha 1$ ), which is 12 amino acids longer due to an insertion (and a further amino acid is changed from proline to alanine), have a severely reduced divalent permeability (but this has only been tested for $\mathrm{Ca}^{2+}$ and $\mathrm{Mg}^{2+}$ ions so far). The region of TRPM1 proteins responsible for forming the pore is also subject to alternative splicing [121]. The resulting short-pore TRPM1 channels have a pore region that is longer than the short pore of TRPM3 (due to an insert of seven amino acids) but shorter than the long TRPM3 pore [121, 158]. Short-pore TRPM1 proteins, when heterologously overexpressed, form $\mathrm{Ca}^{2+}$-permeable channels that, however, do not conduct $\mathrm{Zn}^{2+}$ ions [108]. Instead, TRPM1 channels are inhibited by $\mathrm{Zn}^{2+}$ ions (see section "Inhibition of TRP channels by zinc ions"). The permeability of the TRPM1 pore to other divalent cations has so far not been tested. Furthermore, no functional data about long-pore TRPM1 channels have been published. Short-pore TRPM1 and TRPM3 proteins are capable of forming (at least in overexpression systems) heteromultimeric channels that are not permeable to $\mathrm{Zn}^{2+}$. Thus, the pore of TRPM1 appears to be dominant over TRPM3 in this respect [108].

Endogenously expressed TRPM 3 channels in pancreatic $\beta$ cells [223] transport $\mathrm{Zn}^{2+}$ ions well even in the presence of physiological concentrations of $\mathrm{Ca}^{2+}$ and $\mathrm{Mg}^{2+}$ [222]. This has been taken as evidence that TRPM3 channels in pancreatic $\beta$ cells are not heteromultimers of TRPM3 and TRPM1 proteins. No data on the permeability of trace metal ions of endogenously expressed TRPM1 channels are available so far. Recently, TRPM3 channels have been found to have a secondary ion-conducting pathway akin to " $\omega$ pathways" in voltage-gated cation channels [220]. This $\omega$-like pathway opens when TRPM3 channels are stimulated with pregnenolone sulphate and a second chemical agonist like clotrimazole [220]. However, this secondary ion-conducting pathway has been described as monovalent selective and sodium preferring [220], making it unlikely that it contributes to the transport of trace metal ions.

A single TRPM gene is present in the genome of Drosophila melanogaster. It encodes for a channel (dTRPM) permeable to many divalent cations, like $\mathrm{Ca}^{2+}, \mathrm{Mg}^{2+}, \mathrm{Mn}^{2+}, \mathrm{Co}^{2+}$, $\mathrm{Ni}^{2+}$ and, importantly, $\mathrm{Zn}^{2+}$ [49]. The permeability sequence of this channel is given in Table 1. Mutant flies not expressing functional dTRPM channels show a growth defect and die as larvae $[49,71]$. On the cellular level, these animals show reduced cell sizes and an abnormal $\mathrm{Zn}^{2+}$ homeostasis. A partial rescue of the cellular defects of the mutant larva was obtained by supplementing the food with high levels of $\mathrm{Zn}^{2+}$ (but not $\mathrm{Mg}^{2+}$ ) [49].

From the second subgroup of TRPM channels, TRPM4 and TRPM5 are thought to be monovalent selective because they do not conduct $\mathrm{Ca}^{2+}$ ions $[72,110]$. Although not formally shown yet, it seems very likely that these channels also do not conduct other divalent ions such as trace metal ions. TRPM2 channels activated by cADPR or $\mathrm{H}_{2} \mathrm{O}_{2}$ are permeable to $\mathrm{Ca}^{2+}, \mathrm{Mg}^{2+}, \mathrm{Mn}^{2+}$ and $\mathrm{Ba}^{2+}[60,105,131,167,231]$, and again, these permeation properties can be influenced by mutating acidic residues in the presumed pore region [131, 231]. $\mathrm{Mg}^{2+}$ permeability has also been demonstrated for heatactivated TRPM2 [203] and on the single-channel level [205]. All studies found that the permeability of TRPM2 channels to divalent is modest (less than the permeability to $\mathrm{Na}^{+}$ions), and most researchers agree that the permeability for $\mathrm{Mg}^{2+}$ ions is still somewhat less than that for $\mathrm{Ca}^{2+}$ ions $[105$, 203, 205, 231] (but see [131]). Equally, the menthol-activated channels formed by TRPM8 are distinctly permeable to $\mathrm{Ca}^{2+}$, $\mathrm{Mg}^{2+}$ and $\mathrm{Ba}^{2+}$ ions $[130,131] . \mathrm{Mn}^{2+}$ ions also seem to permeate TRPM8 channels, and this can be utilized to quench Fura-2 fluorescence [175]. TRPM8 channels endogenously expressed in the prostate cancer cell line LNCaP display strongly divergent biophysical properties compared to TRPM8 channels in DRG cells (e.g. they have an inward rectifying $\mathrm{I} / \mathrm{V}$ relationship) but also appear to be permeable to $\mathrm{Ca}^{2+}, \mathrm{Sr}^{2+}, \mathrm{Ba}^{2+}$ and $\mathrm{Mn}^{2+}[202]$.

The TRPM channels GON-2 and GTL-1 of Caenorhabditis elegans are permeable for divalent cations and conduct $\mathrm{Mg}^{2+}$ under bi-ionic conditions [199]. However, it is unclear whether $\mathrm{Mg}^{2+}$ can also be conducted by these channels under physiological $\mathrm{Ca}^{2+}$ concentrations [232]. Nevertheless, worms lacking both GON-2 and GTL-1 display a severe lack of $\mathrm{Mg}^{2+}$, indicating that these channels are important for intestinal $\mathrm{Mg}^{2+}$ uptake. In addition, animals deficient in GON-2 and GTL-1 are resistant to $\mathrm{Ni}^{2+}$, suggesting that these channels transport this toxic metal ion. A further TRPM channel from C. elegans, GTL-2, has been implicated in $\mathrm{Mg}^{2+}$ excretion, but its $\mathrm{Mg}^{2+}$ permeability has not been measured with direct methods [200].

\section{Transport of metal ions through TRPV channels}

The family of TRPV channels comprises six members in mammals. The first four members (TRPV1-4) display marked sensitivity to temperature and are therefore counted among the "thermoTRPs" [162]. In general, the permeability profile of the thermosensitive TRPV channels (TRPV1-4) is only poorly known, and that is also true for the otherwise well-studied 
TRPV1 channel. Before TRPV1 was cloned [21], the endogenously expressed vanilloid receptor in DRG cells was known to conduct $\mathrm{Co}^{2+}$ ions [147], and the capsaicin-induced uptake of $\mathrm{Co}^{2+}$ has been used in a number of studies to probe for TRPV1 activity (e.g. [180]). Heterologously expressed TRPV1 is known to be permeable to $\mathrm{Mg}^{2+}$ with a somewhat lower permeability compared to $\mathrm{Ca}^{2+}[2,21,47]$. The permeability to $\mathrm{Mg}^{2+}$ is affected by mutating an asparagine residue in the pore region (D646; [47]). Since the pore diameter of TRPV1 channels is large (accommodating large organic cations; $[13,134])$ especially when dilated upon prolonged agonist stimulation [28], it is rather likely that these channels - at least under some conditions - also conduct other divalent cations, but this has not yet been demonstrated experimentally.

TRPV2 channels have also been shown to conduct $\mathrm{Mg}^{2+}$ with a slightly lower permeability than $\mathrm{Ca}^{2+}[20]$, while recent data on TRPV3 channels indicate that they are inhibited by $\mathrm{Mg}^{2+}$ ions [125]. TRPV3 channels, however, have been found to be permeable to $\mathrm{Sr}^{2+}$ ions, which is exploited to artificially activate oocytes, where TRPV3 is strongly expressed [19]. TRPV4 channels, again, conduct $\mathrm{Mg}^{2+}$ ions, and the permeability of this channel to $\mathrm{Mg}^{2+}$ is specifically abolished by a double mutation in the pore region, which does not severely affect the permeability to $\mathrm{Ca}^{2+}$ [219]. Reversal potential analysis determined that the permeability of TRPV4 to $\mathrm{Ca}^{2+}$ and $\mathrm{Sr}^{2+}$ was higher than that to $\mathrm{Ba}^{2+}$ [191]. Finally, Fura-2 quench was used to show that TRPV4 channels conduct $\mathrm{Mn}^{2+}$ and have a basal, unstimulated channel activity [228]. Other trace metal ions have not been studied with respect to their permeability for TRPV $1-4$.

TRPV5 and TRPV6 are closely related to each other and unique among all TRP channels as they are - under physiological ionic conditions-very $\mathrm{Ca}^{2+}$-selective and display an inward-rectifying I/V curve [67, 68, 163, 164, 213]. It was recognized early on that these channels conduct a variety of divalent cations $\left(\mathrm{Ba}^{2+}, \mathrm{Sr}^{2+}, \mathrm{Mn}^{2+}\right.$ ) but not $\mathrm{Mg}^{2+}$ (which was found to inhibit currents through TRPV5 and TRPV6, see below, section "Inhibition of TRP channels by magnesium ions"). Interestingly, an ortholog of TRPV6 that does conduct $\mathrm{Mg}^{2+}$ has recently been cloned from Xenopus laevis [30]. The strong selectivity of the mammalian channels for $\mathrm{Ca}^{2+}$ (among the physiological divalent cations) led to the conclusion that these channels are important for $\mathrm{Ca}^{2+}$ (re-) uptake in the intestine and in the kidneys, where they are strongly expressed $[67,163,164]$. These early reports also indicated that $\mathrm{Ca}^{2+}$ uptake through TRPV5 and TRPV6 was inhibited by a large number of other divalent and trivalent cations (see section "Inhibition of TRP channels by metal ions"). Recently, however, a re-evaluation of this question provided evidence that TRPV6 is also permeable to $\mathrm{Zn}^{2+}$ and $\mathrm{Cd}^{2+}$ and, surprisingly, also to lanthanum $\left(\mathrm{La}^{3+}\right)$ and gadolinium $\left(\mathrm{Gd}^{3+}\right)$, but not to mercury $\left(\mathrm{Hg}^{2+}\right), \mathrm{Co}^{2+}$ and $\mathrm{Ni}^{2+}$ [101]. The authors propose that, since TRPV6 channels are highly expressed in the placenta $[164,229]$, they could constitute an important route participating in the transplacental transport of trace elements. Similarly, TRPV5 has also been shown to be permeable to $\mathrm{Cd}^{2+}$ and $\mathrm{Zn}^{2+}$ [102]. A calcium-restricted diet has been shown to increase both intestinal TRPV6 (also called CaT1) and intestinal $\mathrm{Cd}^{2+}$ absorption. This supports the hypothesis that TRPV6 channels may be causally responsible for the enhanced uptake of this poisonous trace metal under conditions where $\mathrm{Ca}^{2+}$ is in short supply [135]. Interestingly, a strongly increased plasma $\mathrm{Zn}^{2+}$ concentration in $\mathrm{Ca}^{2+}$-restricted animals has also been noted, which may have been caused by an increased uptake of $\mathrm{Zn}^{2+}$ through TRPV6 channels [135].

Transport of metal ions through TRPML channels

The only known intracellular TRP channels involved in the homeostasis of trace metal ions are TRPML1 (also named mucolipin-1 or MCOLN1) and TRPML2 (or MCOLN2) [39], which both belong to the mucolipins (TRPML). Three TRPML proteins have been identified in mammals: TRPML1, TRPML2 and TRPML3 (or MCOLN3) [171, 212]. TRPML1 is a 580-amino acid glycoprotein with a molecular mass of $65 \mathrm{kDa}$ present in membranes of endo-lysosomal compartments [109, 169, 242]. Northern blot analysis of various human tissues showed that TRPML1 is expressed almost ubiquitously with the exception of the colon and thymus tissues [10]. Mutations in the gene coding for TRPML1 cause mucolipidosis type IV (MLIV) [10, 195], a lysosomal storage disorder characterized by the accumulation of lipids and soluble substances [242]. This autosomal recessive disease is associated with visual, motor and mental impairments [3, $169,242]$. TRPML1 function was inferred from its permeation profile and from physiological consequences of its genetic ablation. Mounting evidence points to a role of TRPML1 and its relatives in trace metal ion permeability. By means of electrophysiological methods and ${ }^{55} \mathrm{Fe}^{2+}$ uptake measurements, Dong et al. [39] showed that TRPML1 and TRPML2 can transport this metal out of endo-lysosomal compartments. The channels are also permeable to a wide range of cations including $\mathrm{Zn}^{2+}, \mathrm{Mn}^{2+}, \mathrm{Ca}^{2+}, \mathrm{Mg}^{2+}, \mathrm{Ni}^{2+}, \mathrm{Co}^{2+}, \mathrm{Cd}^{2+}$ and $\mathrm{Ba}^{2+}$, but they are not permeable to $\mathrm{Fe}^{3+}$ and $\mathrm{Cu}^{2+}$. Surprisingly, TRPML3, a closely related TRPML member, does not transport $\mathrm{Fe}^{2+}$ [39] (although it does conduct $\mathrm{Ca}^{2+}, \mathrm{Sr}^{2+}, \mathrm{Ba}^{2+}$ and $\mathrm{Mg}^{2+}$ as determined in the varitint waddler mutant that is trafficked to the plasma membrane [96, 233]). Skin fibroblasts from MLIV patients have a higher lysosomal iron content than control cells [39]. Recent evidence connects TRPML1 loss to $\mathrm{Fe}^{2+}$-dependent buildup of reactive oxygen species and mitochondrial damage [29]. The impact of $\mathrm{Fe}^{2+}$ accumulation or oxidative stress on tissues affected by MLIV is presently unknown. 
Of note, recent experiments showed that knocking down the expression of TRPML1 in HEK cells mimics the MLIV phenotype with large lysosomes and membranous vacuoles accumulating chelatable $\mathrm{Zn}^{2+}$ [43]. This is specific to TRPML1 because suppressing the expression of TRPML2 does not reproduce this effect. The authors observed higher levels of chelatable $\mathrm{Zn}^{2+}$ in fibroblasts from MLIV patients and also higher brain levels of $\mathrm{Zn}^{2+}$ in TRPML1 ${ }^{-1-}$ mice. They concluded that TRPML1 interferes with the homeostasis of $\mathrm{Zn}^{2+}$ since loss of TRPML1 function is associated with higher levels of chelatable $\mathrm{Zn}^{2+}$ in large lysosomes and vacuolar structures. But, in contrast to Dong et al. [39], they did not observe any modification in the size of the pool of mobilizable $\mathrm{Fe}^{2+}$ [43]. The role of TRPML1 in regulating cellular $\mathrm{Zn}^{2+}$ was recently explored in another set of studies. In agreement with the above-mentioned observations, it was found that TRPML1-deficient cells accumulate $\mathrm{Zn}^{2+}$ in the lysosomes, in a manner that requires or is regulated by a cytoplasmic step [106].

The data discussed above indicate that TRPML1 is responsible for the regulation of the lysosomal $\mathrm{Fe}^{2+}$ and $\mathrm{Zn}^{2+}$ content. TRPML1 permeability to $\mathrm{Fe}^{2+}$ and $\mathrm{Zn}^{2+}$ suggests its role in $\mathrm{Fe}^{2+}$ and $\mathrm{Zn}^{2+}$ leak from the lysosomes, which may be important in tissues that lack other lyso/endosomal divalent transporters such as DMT1. However, the recent evidence of the role of TRPML1 in lysosomal secretion [132, 179] suggests an alternative explanation for the metal buildup in TRPML1-deficient cells: Without the proper functioning of TRPML1 channels, the $\mathrm{Ca}^{2+}$-dependent exocytosis of lysomes is impaired which could by itself lead to reduced excretion of the metal ions that have accumulated in the lysosomes. Thus, the true impact of TRPML1 permeability to $\mathrm{Fe}^{2+}$ and $\mathrm{Zn}^{2+}$ on cellular function remains to be identified.

Transport of metal ions through TRPP channels

TRPP2 proteins (also called PKD2 or PC2) form $\mathrm{Ca}^{2+}$-permeable ion channels $[6,34,59]$ that are capable to co-assemble with members of the PKD1 family of large glycoproteins [59, 208]. On their own, TRPP2 proteins reside intracellulary in the ER membrane and form cation-permeable ion channels that conduct $\mathrm{Ca}^{2+}, \mathrm{Ba}^{2+}$ and $\mathrm{Mg}^{2+}$ ions $[6,100]$. The related proteins TRPP3 (also called PKD2L1 or PKD-L) form channels that are, in addition to $\mathrm{Ca}^{2+}$, also permeable to $\mathrm{Ba}^{2+}, \mathrm{Sr}^{2+}$, $\mathrm{Mg}^{2+}$ and $\mathrm{Mn}^{2+}[23,197]$. Chen et al. [23] found that macroscopic (whole-cell) $\mathrm{Mg}^{2+}$ currents through TRPP3 channels were much smaller than $\mathrm{Ca}^{2+}$ currents. This was, however, only partly reflected in the single-channel conductance of TRPP3 channels that was only $20 \%$ smaller for charge carried by $\mathrm{Mg}^{2+}$ compared to $\mathrm{Ca}^{2+}$ ions [197]. TRPP3 proteins are capable of forming complexes with PKD1L3 proteins that have a 3:1 stoichiometry [240] and respond to the removal of acidic solutions with an "off response" [79]. Because of this sensitivity to $\mathrm{pH}$ changes and their co-expression in a specific, proton-sensitive subgroup of taste receptor cells [78, 84, 123], these proteins have been implicated in the sensation of sour taste [78, 84]. However, sour-sensitive taste cells possess a proton-influx channel that is specifically active when exposed to a low extracellular $\mathrm{pH}$ [22]. The channel complex of PKD1L3 and TRPP3, on the other hand, is inhibited during exposure to extracellular protons and only opens with an "off response" when the proton concentration drops [79, 94]. Furthermore, single and double knockout mice in which PKD1L3 and TRPP 3 proteins have been inactivated still respond to acidic tastants in electrophysiological experiments albeit with reduced intensity compared to wild type [75, 151]. It is therefore unclear whether and to what extent TRPP3-PKD1L3 complexes contribute to the transduction channels in soursensitive taste cells. Overexpressed TRPP3-PKD1L3 channel complexes conduct $\mathrm{Ca}^{2+}$ and $\mathrm{Mg}^{2+}[79,240]$. Through specific mutations in the putative pore regions of TRPP3 and PKD1L3, the altered permeability to $\mathrm{Mg}^{2+}$ has been used to determine that both proteins participate in the ion-conducting pore [240].

In primary cilia, TRPP3 channels form complexes with PKD1L1, another member of the PKD1 family [33]. These channels are divalent permeable and have the same relative permeability for $\mathrm{Ca}^{2+}$ and for $\mathrm{Ba}^{2+}[32]$.

An overview of the data discussed in this section is given in Table 1. It contains the list of the metal ions transported by TRP channels and, when established, their permeability sequence. As can be seen, $\mathrm{Zn}^{2+}$ ions are, after the well-studied $\mathrm{Ca}^{2+}$ and $\mathrm{Na}^{+}$ions, the most frequently studied ions. They permeate members of most TRP subfamilies (TRPA, TRPC, TRPM, TRPML and TRPV). However, permeability for $\mathrm{Zn}^{2+}$ cannot be regarded as a general and common property of $\mathrm{Ca}^{2+}$-conducting TRP channels (see, e.g. TRPM1). Table 1 illustrates that TRP channels are capable to finely tune their ion selectivity and to discriminate precisely between different divalent cations.

\section{Activation and potentiation of TRP channels by metal ions}

Like other ion channels, TRP channels can be differentially affected by trace metal ions. Often, they are inhibited (see section "Inhibition of TRP channels by metal ions") ormuch more rarely - activated or potentiated by these ions. In the next section, we will summarize these rare examples, which are also summarized in Table 2 and are graphically illustrated in Fig. 1.

Activation and potentiation of TRPA channels

The trace metal $\mathrm{Zn}^{2+}$ is the only physiologically relevant trace metal that activates TRPA1 channels [77] or any other TRP 
Table 2 TRP channels activated or potentiated by metal ions

\begin{tabular}{llll}
\hline Channel & Metal ions & Effect & References \\
\hline TRPA1 & $\mathrm{Cu}^{2+}, \mathrm{Zn}^{2+}, \mathrm{Cd}^{2+}$ & Activation & {$[4,77]$} \\
TRPC5 & $\mathrm{Pb}^{2+}$ & Activation & {$[194]$} \\
and / or & $\mathrm{La}^{3+}, \mathrm{Gd}^{3+}$ & Activation or Potentiation & {$[88,181,186,234]$} \\
TRPC4 & $\mathrm{mercurial}^{2+}$ compounds & Activation & {$[235]$} \\
TRPV1 & $\mathrm{Cu}^{2+}, \mathrm{Mg}^{2+}, \mathrm{Fe}^{2+}, \mathrm{Zn}^{2+}, \mathrm{Ni}^{2+}$ & Activation & {$[2,18,124,174,238]$} \\
& $\mathrm{Cu}^{2+}, \mathrm{Mg}^{2+}, \mathrm{La}^{3+}, \mathrm{Gd}^{3+}$ & Potentiation & {$[207,226]$} \\
TRPV6 & $\mathrm{Zn}^{2+}, \mathrm{La}^{3+}$ & Potentiation & {$[101]$} \\
\hline
\end{tabular}

channel. TRPA1 channels are activated by intracellular $\mathrm{Zn}^{2+}$ ions in a concentration range from $>1$ to $1,000 \mathrm{nM}[4,77]$. In rat DRG sensory neurons, elevation of the intracellular concentration of free $\mathrm{Zn}^{2+}$ to $10-20 \mathrm{nM}$ activates TRPA1 channels, and such an activation also occurs with $\mathrm{Cu}^{2+}$ (with an $\mathrm{EC}_{50}$ of $\sim 0.6-1 \mu \mathrm{M}$ ), $\mathrm{Cd}^{2+}$ (with an $\mathrm{EC}_{50}$ of $\sim 1-2 \mu \mathrm{M}$ ) and $\mathrm{Ba}^{2+}$ (without quantification, [227]). On the other hand, TRPA1 channels are not activated by $\mathrm{Fe}^{2+}, \mathrm{Na}^{+}$[4] or $\mathrm{Mg}^{2+}$ [227]. Interestingly, $\mathrm{Zn}^{2+}$ ions that activate TRPA1 channels may have entered the cell through TRPA1 channels themselves, as the potentiation by trace metals (or $\mathrm{Ca}^{2+}$ ) is abolished [77] by a mutation (D918A) that strongly reduces $\mathrm{Ca}^{2+}$ permeability of the channels (see section "Transport of metal ions through TRPA channels") [227]. This property is of physiological relevance because injection of $\mathrm{Zn}^{2+}$ in mice elicits nociceptive responses, dependent on TRPA1 expression [77]. The $\mathrm{Zn}^{2+}$ (and $\mathrm{Cd}^{2+}$ ) sensitivity of TRPA1 is not shared by other TRP channels expressed in nociceptor neurons (TRPV1, TRPV2, TRPV3, TRPV4 and TRPM8), making this channel the physiologically relevant $\mathrm{Zn}^{2+}$-sensitive detector for nociception. The patho-physiological relevance of trace metal-activated TRPA1 channels has recently been confirmed in the respiratory system [55]. TRPA1 channels are expressed by a sub-population of capsaicin-sensitive pulmonary neurons, and therefore, the application of $\mathrm{Zn}^{2+}$ ions (but also of $\mathrm{Cd}^{2+}$ or $\mathrm{Cu}^{2+}$ ) gives rise to an inward current mediated by TRPA 1 channels. On the whole animal level, $\mathrm{Zn}^{2+}$ exposure causes a marked depression of the respiratory rate in wild-type mice but not in TRPA1 ${ }^{-/}$mice [55].

Recently, TRPA1 channels have also been implicated in the etiology of neuropathic pain induced by $\mathrm{Pt}^{2+}$-containing anticancer medication (cisplatin and oxaliplatin). These substances represent important chemotherapeutic agents commonly used for the treatment of various tumours [225]. However, they have major, potentially dose-limiting side effects such as painful allodynia (cold allodynia is especially severe with oxaliplatin treatment) and pronounced ototoxicity due to death of cochlear cells (seen especially during treatment with cisplatin). TRPA1 was specifically found to be necessary for oxaliplatin-evoked cold allodynia, as the development of cold allodynia was impaired or absent after pharmacological blockade of TRPA1 channels or in TRPA1-deficient animals [148, 149]. Cisplatin and oxaliplatin also activated overexpressed TRPA1 channel. TRPA1 activation was abolished by glutathione, indicating that the $\mathrm{Pt}^{2+}$-containing substances do not activate TRPA1 channels directly, but rather cause the generation of reactive chemical species (for instance, reactive oxygen species) that in turn activate TRPA1 channels [148]. In isolated DRG neurons, Nassini et al. [148] did not observe activation of TRPA1-expressing neurons by $\mathrm{Pt}^{2+}$-containing substances and therefore suggested that in vivo the reactive chemical species are produced by other (non-neuronal) cells in the surroundings of the TRPA1-expressing nociceptors. Zhao et al. [244], however, found in isolated DRG neurons that

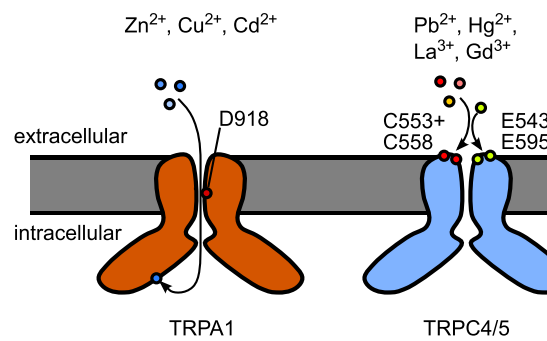

Fig. 1 Activation or potentiation of TRP channels by divalent or trivalent trace metal ions. Indicated are the TRP channels for which an activation or potentiation has been positively identified. Please note that activating effects of $\mathrm{Ca}^{2+}$ ions (described for TRPV1) are not depicted. Where identified, amino acid residues important for the activation or potentiation of the channel activity are indicated. Due to the tetrameric symmetry of TRP channels, the shown residues are found on each subunit but are

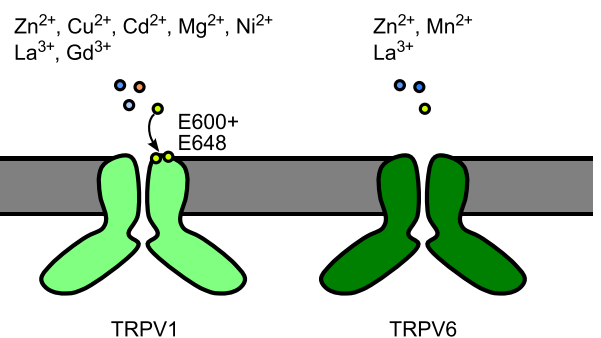

depicted only on one subunit. For TRPA1, the aspartate 918 most likely is important for the permeation of $\mathrm{Zn}^{2+}$ and other divalent cations, and by this means regulates their potentiating effect. For TRPC5, the indicated cystein residues have been characterized to be important for the activation by $\mathrm{Hg}^{2+}$, while the glutamate residues are important for the activation by lanthanides and $\mathrm{Pb}^{2+}$ 
oxaliplatin treatment for 2-4 h increased the number of allylisothionate (the prototypical TRPA1 agonist) sensitive cells indicating that some of the effects of oxaliplatin may be cell autonomous.

\section{Activation and potentiation of TRPC channels}

The trivalent "rare earth elements" (or lanthanide ions) $\mathrm{La}^{3+}$ and $\mathrm{Gd}^{3+}$ have been heavily used to inhibit most mammalian TRP channels (see section "Inhibition of TRP channels by lanthanides"). It is therefore surprising that these ions also potentiate a small number of mammalian TRP channels. Nevertheless, this behaviour has been very well documented for TRPC4 and TRPC5 channels pre-activated by GTP $\gamma \mathrm{S}$ [181]. Additionally, heteromultimeric TRPC1-TRPC5 channels are also activated by $\mathrm{La}^{3+}$ [192]. It was subsequently reported that human TRPC5 channels can be directly activated by $\mathrm{Gd}^{3+}$ even without exogenous receptor activation [243]. The potentiating effect of $\mathrm{La}^{3+}$ on mouse TRPC5 channels expressed in HEK cells are more pronounced at negative potentials and are fully reversible upon washout [88]. This stimulating effect is seen for concentrations of $\mathrm{La}^{3+}$ and $\mathrm{Gd}^{3+}$ ranging from 1 to $1,000 \mu \mathrm{M}$ [88]. At still higher concentrations $(5 \mathrm{mM}), \mathrm{La}^{3+}$ blocks TRPC5 current. Extracellular $\mathrm{Ca}^{2+}$ ions are also capable of stimulating TRPC5 channels (concentration range 2$20 \mathrm{mM}$ ) [88, 243]. At $20 \mathrm{mM}$ extracellular $\mathrm{Ca}^{2+}, \mathrm{La}^{3+}$ ions were found not to have an additional potentiating effect, indicating that $\mathrm{Ca}^{2+}$ competes with $\mathrm{La}^{3+}$ for the same binding site [88]. Single-channel measurements reveal a complex mode of action in which $\mathrm{Gd}^{3+}$ decreases the amplitude of unitary currents through mouse TRPC 5 channels but simultaneously increases the open probability strongly, resulting in a larger net current $[88,186]$. Two negatively charged glutamate residues $\left(\mathrm{Glu}^{543}\right.$ and $\mathrm{Glu}^{595}$ ), close to the extracellular mouth of the pore, are controlling the positive regulatory processes [88]. The same amino acids are also important for the activation of TRPC 5 channels by $\mathrm{Ca}^{2+}$ ions [88].

Besides lanthanides, methyl mercury (MeHg) stimulates the activity of some TRP channels. The application of $\mathrm{MeHg}$ and divalent mercury $\left(\mathrm{Hg}^{2+}\right)$ gives rise to an influx of $\mathrm{Ca}^{2+}$ in HEK cells overexpressing human TRPC5 channels and in cultured human umbilical vein endothelial cells, which endogenously express TRPC5 channels [235]. The response to $\mathrm{Hg}^{2+}$ was prevented by 2-APB, a blocker of many TRP channels, and DTT. Consequently, the replacement of two cysteine residues (C553 and C558) located near the third extracellular loop (E3) abolishes the metal-dependent potentiation of the $\mathrm{Ca}^{2+}$ entry. These sites differ from the putative lanthanide-binding site. Accordingly, the effects of mercurial compounds, that act extracellularly, are additive with, and hence independent of those of lanthanides [235]. Mercurial compounds have also been shown to exert a positive regulatory effect on the closely related TRPC4 channel but not on
TRPC3, TRPC6, TRPV1 and TRPV2. $\mathrm{Ni}^{2+}, \mathrm{Cd}^{2+}$ and $\mathrm{Zn}^{2+}$ do not mimic the effects of mercurial compounds. Lead ions, however, at concentrations $>5 \mu \mathrm{M}$ augment $\mathrm{Ca}^{2+}$ entry through TRPC5 channels [194, 235], but the magnitude of the effect reported was variable between the two studies. A glutamate residue located at position 543 seems to control the $\mathrm{Pb}^{2+}$-dependent regulation of TRPC5 [194]. The molecular effect of $\mathrm{Pb}^{2+}$ therefore seems similar to the one underlying the stimulatory effects of lanthanides, as the same glutamate residue appears to be involved.

\section{Activation and potentiation of TRPV channels}

Similar to TRPC4 and TRPC5, channels composed of TRPV1 proteins also are activated by lanthanides. In HEK-293T cells expressing recombinant rat TRPV1 channels, the application of $\mathrm{Gd}^{3+}$ at concentrations of $10-1,000 \mu \mathrm{M}$ elicits currents, indicating direct activation of TRPV1 channels by $\mathrm{Gd}^{3+}$. However, at concentrations $>300 \mu \mathrm{M}$, the currents elicited by $\mathrm{Gd}^{3+}$ are reduced, indicating that $\mathrm{Gd}^{3+}$ causes an additional block of TRPV1 currents at these high concentrations [207]. In addition, at concentrations lower than $100 \mu \mathrm{M}, \mathrm{Gd}^{3+}$ potentiates TRPV1 activity induced by heat, protons and capsaicin. Again, however, at $1 \mathrm{mM}, \mathrm{Gd}^{3+}$ inhibits these agonistinduced currents through TRPV1 channels. The $\mathrm{Gd}^{3+}$-dependent potentiation seems to involve two glutamate residues at position 600 and 648. Mutating E648 to alanine severely shifted the dose-response curve of $\mathrm{Gd}^{3+}$ to higher values, while the corresponding mutation of E600 completely abolished the activation of TRPV1 by $\mathrm{Gd}^{3+}$ [207]. Both of these glutamate residues are thought to be located at the extracellular side of the membrane and are implicated in the activation of TRPV1 by protons [87]. Therefore, it was proposed that $\mathrm{Gd}^{3+}$ might exert its activating effect similarly to protons [207]. In the light of these results, it is surprising that another study did not find that $\mathrm{Gd}^{3+}$ (up to a concentration of $100 \mu \mathrm{M})$ affects $\mathrm{Ca}^{2+}$ signals evoked by stimulating TRPV1 channels with protons ( $\mathrm{pH} 5$ ) or capsaicin [185].

Some other monovalent and multivalent cations activate TRPV1 channels, most notably $\mathrm{Mg}^{2+}$. This question was studied in some detail by Ahern et al. [2] who found that TRPV1 channels can be activated by $\mathrm{Mg}^{2+}, \mathrm{Ca}^{2+}$ and also lithium ions $\left(\mathrm{Li}^{+}\right)$with the following sequence: $\mathrm{Ca}^{2+}=$ $\mathrm{Mg}^{2+}>>\mathrm{Li}^{+}>>\mathrm{Na}^{+}$. As seen with $\mathrm{Gd}^{3+}$, these cations exert a direct effect on the gating of the channels but only at very high concentrations (e.g. $\geq 30 \mathrm{mM} \mathrm{Mg}^{2+}$ ). On the other hand, they also sensitize TRPV1 channels already at lower concentrations (e.g. $3-5 \mathrm{mM} \mathrm{Mg}^{2+}$ ) by shifting the doseresponse of capsaicin (and endogenous ligands like AEA and NADA) to lower values. $\mathrm{MgSO}_{4}$ also induces pain in vivo, as injecting it intraperitoneally caused writhing in wild-type mice but not in TRPV1 ${ }^{-/-}$mice [2]. During inflammation, these processes may have pathophysiological 
importance, as evidence was provided that TRPV1 channels, once sensitized with bradykinin, already react to $\mathrm{Mg}^{2+}$ ions at physiological concentrations [2]. Importantly, in these sensitized TRPV1 channels, the temperature activation was shifted to lower temperatures by $\mathrm{Mg}^{2+}$ [2]. Subsequent works found that $\mathrm{Cu}^{2+}, \mathrm{Fe}^{2+}, \mathrm{Zn}^{2+}, \mathrm{Ni}^{2+}$ and $\mathrm{Ba}^{2+}$ ions all activate TRPV1 channels $[18,124,174,206,207$, 238]. The two glutamate residues (E600 and E648) that mediate activation of TRPV1 by $\mathrm{Gd}^{3+}$ are also important in the regulation of TRPV1 channels by other divalent cations. A recent in-depth analysis, however, found that most extracellular regions of TRPV1 channels are involved in the regulation by $\mathrm{Mg}^{2+}$ and $\mathrm{Ba}^{2+}$ [238]. In this study, it was also shown that $\mathrm{Mg}^{2+}$ and $\mathrm{Ba}^{2+}$ exerted their activating effect mainly by facilitating heat activation of TRPV1 and thereby lowering the temperature threshold for activation $[18,238] . \mathrm{Mg}^{2+}$ was shown to induce a conformational change similar to that caused by heat [238]. An interesting species difference with respect to $\mathrm{Mg}^{2+}$ sensitivity of TRPV1 was discovered by Wang et al. [226]. They found that external application of $5 \mathrm{mM} \mathrm{Mg}{ }^{2+}$ augments the basal current (without agonist stimulation and at room temperature) through human TRPV1 channels much more effectively than through rat TRPV1 channels (which were studied in ref. [2]). At saturating capsaicin concentrations (which eliminate effects of sensitization of the capsaicin effect), $\mathrm{Mg}^{2+}$ still enhances human TRPV1 while it moderately blocks rat TRPV1. Wang et al. [226] identified the protein region between transmembrane segments S5 and S6 as the molecular part of TRPV1 channels controlling this species difference in $\mathrm{Mg}^{2+}$ sensitivity.

Apart from nociception, the activation of TRPV1 channels by multivalent cations has also been discussed in the context of taste sensation transmitted by the trigeminal system. Divalent cations such as $\mathrm{Cu}^{2+}, \mathrm{Fe}^{2+}$ and $\mathrm{Zn}^{2+}$ are considered to be complex tasting because at low concentrations, they elicit an attractive response, while at higher concentrations, they are aversive [174]. As TRPV1 channels are strongly expressed in trigeminal fibres in the orofacial cavity (e.g. [82]), TRPV1 channels were good candidates for mediating the aversive component of the taste of these salts. However, only for $\mathrm{FeSO}_{4}$, a difference between TRPV1 ${ }^{-/}$and wild-type mice could be established [174], and TRPV1-deficient mice still show a strong aversion to all of these salts. This indicates that other receptors for these salts are important in this system. Given the fact that $\mathrm{Zn}^{2+}$ strongly activates TRPA1 channels [77], which are also expressed in trigeminal nociceptor neurons, these proteins might be interesting candidates.

Mukherjea et al. [142] reported that the anti-cancer drug cisplatin activates TRPV1 channels directly, leading to increased $\mathrm{Ca}^{2+}$ influx in immortalized organ-of-corti cells (UB/OC-1). TRPV1 activation by cisplatin was therefore implicated in cisplatin-induced hearing loss, and indeed, reducing TRPV1 expression (by siRNA treatment) or TRPV1 activity (by capsazepine or ruthenium red) in the inner ear reduced cisplatin-induced hearing loss [142].

Human TRPV6 channels are modulated by $\mathrm{Zn}^{2+}$. Low concentrations of extracellular $\mathrm{Zn}^{2+}$ (but also $\mathrm{Mn}^{2+}$ and $\mathrm{La}^{3+}$ ) increase $\mathrm{Ca}^{2+}$ currents or radioactive $\mathrm{Ca}^{2+}$ uptake through hTRPV6 channels slightly $(<50 \%)$ whereas at higher concentrations, these metal ions depress hTRPV6-dependent $\mathrm{Ca}^{2+}$ currents [101].

\section{Inhibition of TRP channels by metal ions}

Divalent cations generally permeate channels by binding to negatively charged amino acid residues located in the ionconducting pore. While this ensures their efficient permeation, this process also prevents the permeation of other ions (for instance, monovalent cations). This is the reason why all permeating trace metal ions - at least to some degree - are also inhibitors of the currents carried by monovalent cations through these channels. In this section, we will, however, concentrate on cases where inhibition of TRP channels by trace metal ions appears to follow a different mechanism than the concept of "sticky" permeant blockers [64].

\section{Inhibition of TRP channels by lanthanides}

$\mathrm{La}^{3+}$ was already used to inhibit fly TRP channels well before it was established that its mode of action is to block the conduction of ions through plasma membrane channels [66]. It was later shown that $10-20 \mu \mathrm{M}$ of $\mathrm{La}^{3+}$ ions (and the related $\mathrm{Gd}^{3+}$ ions) strongly block TRP channels while leaving TRPL channels almost unaffected [61, 152, 172]. In the following years, almost all TRP channels identified were found to be inhibited by these lanthanides, albeit within vastly differing concentration ranges. This has been abundantly demonstrated in TRPC channels, which are the mammalian TRP channels most closely related to Drosophila TRP and TRPL channels: TRPC1 [187, 247], TRPC5 (but only at millimolar concentrations: [88]), TRPC6 [15, 81] and TRPC7 [160, 173] are inhibited by lanthanides. Depending on the expression system, TRPC3 responses were described as poorly sensitive or fully blocked by $\mathrm{La}^{3+}[90,245,246]$. It was later shown that, at least in certain cell types, $\mathrm{La}^{3+}$ - and $\mathrm{Gd}^{3+}$ — can passively enter into the cytosol where they exert a stronger inhibitory effect compared to extracellular application [58]. Of note, intracellularly, lanthanides bind to negatively charged compounds and may act as complexes rather than as free ions [58].

TRPM channels have been generally found to be rather poorly sensitive to lanthanides. TRPM2 channels appeared to be essentially insensitive to external application of $\mathrm{La}^{3+}$, as $1 \mathrm{mM} \mathrm{La}^{3+}$ only caused a weak diminution of the current through TRPM2 channels at most, irrespective of whether 
these channels were overexpressed in HEK293 cells or endogenously expressed in microglia $[54,105]$. TRPM3 channels, on the contrary, are reasonably well blocked by $\mathrm{Gd}^{3+}$, as $100 \mu \mathrm{M}$ were shown to inhibit the constitutive activity [53, 113], the sphingosine-induced activity [70] and the pregnenolone sulphate-induced activity [150]. Two different studies found that TRPM4 channels are inhibited by $\mathrm{Gd}^{3+}$ or $\mathrm{La}^{3+}$. Approximately $50 \%$ inhibition by $30 \mu \mathrm{M} \mathrm{Gd}^{3+}$ was proposed [139] when these channels were activated by mechanical stretch - which is, however, not a generally accepted stimulus to open TRPM4 channels [214]. Xu et al. described a $\mathrm{Ca}^{2+}$ permeable channel after overexpression of TRPM4 that could be inhibited by $80 \mu \mathrm{M} \mathrm{La}^{3+}$ or $\mathrm{Gd}^{3+}$ [236]. The situation is similar for TRPM5, which was described as a store-operated channel inhibited by $100 \mu \mathrm{M} \mathrm{La}^{3+}$ [166]. However, nowadays, TRPM4 and TRPM5 channels are considered to be activated by $\mathrm{Ca}^{2+}$, but impermeable to this ion $[72,110,155]$. TRPM7 channels were found to be insensitive to $10 \mu \mathrm{M} \mathrm{La}^{3+}$ or $\mathrm{Gd}^{3+}$ [137]. At $10 \mathrm{mM}$, however, $\mathrm{Gd}^{3+}$ blocked inward and outward currents completely [137]. $\mathrm{La}^{3+}$ ions at 2 and $10 \mathrm{mM}$ were found to block inward currents through TRPM7 (almost) completely, while outward currents were only partially inhibited even at these very high concentrations $[137,176]$. In a similar vein, complete inhibition of TRPM7-induced cell rounding was reported to require $2 \mathrm{mM} \mathrm{La}^{3+}$ [193].

The icilin-activated TRPM 8 channels are blocked by $1 \mathrm{mM}$ $\mathrm{La}^{3+}$ [26]. However, $10 \mu \mathrm{M} \mathrm{La}^{3+}$ was ineffective in blocking menthol-activated TRPM8 in an overexpression system [210]. Consistently, TRPM8 channels in corneal epithelial cells were recently found to be partially inhibited by $100 \mu \mathrm{M} \mathrm{Gd}^{3+}$ [133]. Compared to the weak sensitivity to lanthanides of mammalian TRPM channels, the TRPM channels of C. elegans, GTL1 and GON-2, are rather sensitive to $\mathrm{La}^{3+}$ as they are inhibited with an $\mathrm{IC}_{50}$ of approximately $5 \mu \mathrm{M}$ [232].

In general, TRPV channels are inhibited by $\mathrm{Gd}^{3+}$ or $\mathrm{La}^{3+}$. However, these lanthanides are used rather seldom on TRPV1 channels because the members of this subfamily are more sensitive to ruthenium red (which therefore has been preferred for functional assays). It is commonly accepted that TRPV1 is inhibited by $\mathrm{Gd}^{3+}$ only at very high concentrations, if at all. For example, $\mathrm{Gd}^{3+}$ reduced proton- and temperature-evoked TRPV1 currents only at $1 \mathrm{mM}[185,207]$. On the other side, $\mathrm{La}^{3+}$ inhibited uptake of the fluorescent organic cation YOPRO-1 through TRPV1 with an $\mathrm{IC}_{50}$ of $74 \mu \mathrm{M}$ [9]. It is unclear whether this large difference in sensitivity is due to differences between $\mathrm{Gd}^{3+}$ and $\mathrm{La}^{3+}$, or if the YO-PRO-1 uptake assay is particularly sensitive to lanthanides. $\mathrm{La}^{3+}$ or $\mathrm{Gd}^{3+}$ at $100 \mu \mathrm{M}$ blocks heat-activated rat TRPV2 by approximately $60 \%$ [114]. However, Juvin et al. [89] found that mouse TRPV2 channels activated by 2-APB are not inhibited by these lanthanides at the same concentration. Here again, it is unclear what the reason is for this contradiction. TRPV3 channels seem to be more sensitive to $\mathrm{Gd}^{3+}$ than TRPV1 channels as they are inhibited by $\mathrm{Gd}^{3+}$ at concentrations as low as $10 \mu \mathrm{M}$ [207]. TRPV4 channels are again rather poorly sensitive to lanthanides. Early on, it was reported that $100 \mu \mathrm{M}$ $\mathrm{Gd}^{3+}$ causes a $70 \%$ inhibition of TRPV4 currents, while the same concentration of $\mathrm{La}^{3+}$ evoked only a $27 \%$ inhibition [190]. Liedtke et al. [119] reported a voltage-dependent block (incomplete at outward currents) of $500 \mu \mathrm{M} \mathrm{Gd}^{3+}$. More recently, in CHO cells, overexpression of TRPV4 was shown to allow regulatory volume decrease (RVD) upon exposure to hyposmotic solution, and this TRPV4-dependent RVD could be blocked by $100 \mu \mathrm{M} \mathrm{Gd}^{3+}$ [12]. Specific neuronal DRG cells respond to hyposmotic stimuli with an inward current that could not be detected in TRPV4-deficient mice. Surprisingly, this inward current appears to be completely blocked by the rather low concentration of $10 \mu \mathrm{M} \mathrm{Gd}^{3+}$ [111].

Compared to TRPV1-4, TRPV5 channels are highly sensitive to lanthanides and are reported to be inhibited by $\mathrm{La}^{3+}$ with an $\mathrm{IC}_{50}$ of $4.6 \mu \mathrm{M}$ and by $\mathrm{Gd}^{3+}$ with an $\mathrm{IC}_{50}$ of $1.1 \mu \mathrm{M}$ [215]. Similarly, TRPV6 channels are completely blocked by $10 \mu \mathrm{M} \mathrm{La}^{3+}[17,241]$.

TRPA1 channels are inhibited by $\mathrm{La}^{3+}$ and $\mathrm{Gd}^{3+}$ whereby the $\mathrm{IC}_{50}$ value depends strongly on the extracellular $\mathrm{Ca}^{2+}$ concentration [8]. At approximately physiological $\mathrm{Ca}^{2+}$ concentrations $(2 \mathrm{mM}), \mathrm{IC}_{50}$ values of $300 \mu \mathrm{M}$ for $\mathrm{La}^{3+}$ and $167 \mu \mathrm{M}$ for $\mathrm{Gd}^{3+}$ were reported. At $20 \mu \mathrm{M} \mathrm{Ca}^{2+}$, however, the lanthanides are much more potent $\left(\mathrm{IC}_{50}\right.$ for $\mathrm{La}^{3+}$ of $54 \mu \mathrm{M}$ and for $\mathrm{Gd}^{3+}$ of $24 \mu \mathrm{M}$ ) [8]. This finding agrees with earlier data on the block of the uptake of the fluorescent dye YOPRO-1 $\left(\mathrm{IC}_{50}=30-52 \mu \mathrm{M}\right.$; $\left.[8,9]\right)$ or allyl-isothiocyanateinduced current (block by $\mathrm{Gd}^{3+}$ with $\mathrm{IC}_{50}=0.1 \mu \mathrm{M}$; [145]) that were also obtained under low $\mathrm{Ca}^{2+}$ or $\mathrm{Ca}^{2+}$ free conditions.

TRPML1 channels are inhibited by $100 \mu \mathrm{M} \mathrm{La}^{3+}$ and $\mathrm{Gd}^{3+}$ [40], while TRPML3 currents were reported by one study to be much more sensitive with an $\mathrm{IC}_{50}$ of $15 \mu \mathrm{M}$ for wild-type channels and those that harbour so-called "varitint waddler" mutations [146]. Another study, however, found only a partial inhibition even with concentrations as high as $300 \mu \mathrm{M}$ [56]. TRPP2 channels, either alone $[6,51]$ or in a heteromultimeric complex with PKD1 [34] or TRPC1 [7], are inhibited by $\mathrm{Gd}^{3+}$. Interestingly, the heteromultimeric complexes were found to be more potently blocked $\left(\mathrm{IC}_{50}=22-32 \mu \mathrm{M}\right.$, [7]) than the TRPP2 channels obtained from ER membranes of TRPP2 overexpressing cells $\left(\mathrm{IC}_{50}=206 \mu \mathrm{M}\right.$, [6]). Heteromultimeric channels formed from TRPP3 and PKD1L3 proteins are not inhibited by $100 \mu \mathrm{M} \mathrm{Gd}^{3+}$ [83]; however, heteromultimeric complexes made of TRPP3 and PKD1L1 are strongly inhibited by $\mathrm{Gd}^{3+}$ or $\mathrm{La}^{3+}$ at $10 \mu \mathrm{M}$ [32].

Inhibition of TRP channels by zinc ions

$\mathrm{Zn}^{2+}$ ions are able to modulate the activity of numerous voltage- and ligand-gated channels, and TRP channels are no exception to this rule (Fig. 2). For instance, $\mathrm{Zn}^{2+}$ ions 


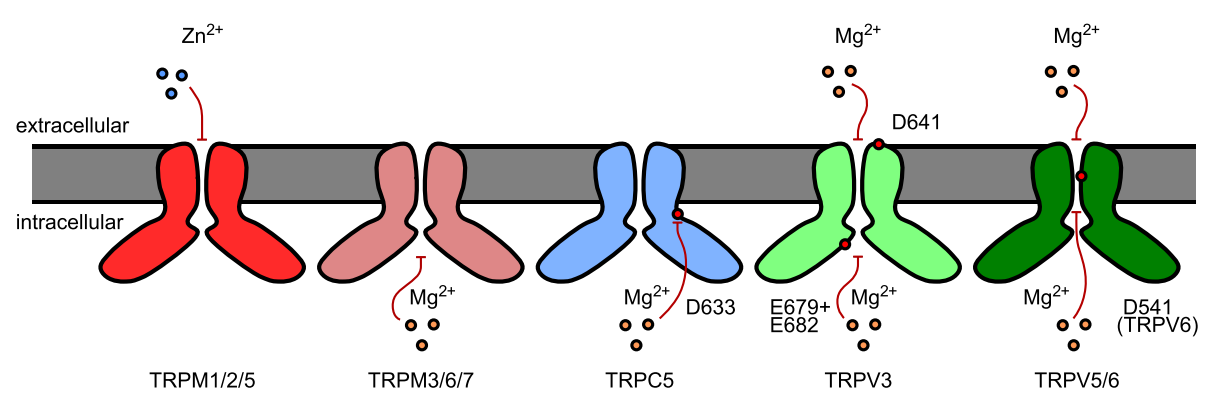

Fig. 2 Inhibition of TRP channels by the physiologically relevant trace metal ions $\mathrm{Zn}^{2+}$ and $\mathrm{Mg}^{2+}$. While $\mathrm{Zn}^{2+}$ inhibits TRPM1, TRPM2 and TRPM5 channels from the extracellular side, $\mathrm{Mg}^{2+}$ ions exert their effect on various TRP channels mainly via the cytosolic side. Note that the inhibition of TRPV1 and TRPA1 channels by $\mathrm{Mg}^{2+}$ is not depicted, as it has only been described to occur at high concentrations (see text). Indicated amino acid residues have been identified as crucial for the depicted inhibitory effect inhibit mouse TRPM1, and a molecular understanding of this inhibitory property has been provided [108]. The pore of TRPM1 channel is permeable to $\mathrm{Ca}^{2+}$ but not to $\mathrm{Zn}^{2+}$ ions that instead block TRPM1 currents with an $\mathrm{IC}_{50}$ of approximately $1 \mu \mathrm{M}$ [108]. This is in stark contrast to TRPM3 channels that are very similar in the primary amino acid sequence of the pore region but conduct $\mathrm{Zn}^{2+}$ (see section "Transport of metal ions through TRPM channels"). This difference has been ascribed to a stretch of seven residues (called the LYAMEIN motif) only present in the pore region of TRPM1 but not in TRPM3. Adding the LYAMEIN motif to the pore of TRPM3 renders it susceptible to block by $\mathrm{Zn}^{2+}$ [108]. Beside the LYAMEIN motif, additional parts of the channel seem important for the $\mathrm{Zn}^{2+}$ sensitivity like the residue histidine 1034 [108].

TRPM2 channels are inhibited by extracellular $\mathrm{Zn}^{2+}$ [188]. In a more recent study, it was reported that these metal ions induce an irreversible and concentration-independent depression of TRPM2-dependent currents [239]. $\mathrm{Zn}^{2+}$ interacts with the outer pore and induces conformational changes leading to the inactivation of the channels [239]. It does not act on channels in the closed state but only on open channels. Since TRPM2 is expressed in microglial cells and in neurons of the hippocampus, a $\mathrm{Zn}^{2+}$-rich brain structure, the authors propose that this mechanism of $\mathrm{Zn}^{2+}$-dependent inhibition of TRPM2 channels could play a neuroprotective role [239]. This process could also constitute a negative feedback mechanism regulating insulin secretion in the pancreas, where TRPM2 channels are expressed in the $\mathrm{Zn}^{2+}$-releasing $\beta$ cells [203]. In addition, TRPM5 channels are inhibited by extracellular $\mathrm{Zn}^{2+}$ ions with an $\mathrm{IC}_{50}$ of $4 \mu \mathrm{M}$, and amino acids important for this process have been identified at the extracellular side of the ionconducting pore [209]. TRPM7 channels are inhibited from the intracellular side by $\mathrm{Zn}^{2+}$ (and other divalent cations like $\mathrm{Ba}^{2+}$ and $\mathrm{Mn}^{2+}$; see also section "Inhibition of TRP channels by magnesium ions") [103]. Altogether, $\mathrm{Zn}^{2+}$ ions exert complex actions on TRPM channels: Depending on the isoform, they can inhibit (e.g. TRPM1 and TRPM5) or inactivate TRPM channels (e.g. TRPM2).
$\mathrm{Zn}^{2+}$ ions exert a dual action on TRPV6 channels. Notwithstanding the fact that $\mathrm{Zn}^{2+}$ ions permeate through the pore of TRPV6 channels, at low concentrations $(20 \mu \mathrm{M}$ and less), they also augment currents carried by $\mathrm{Ca}^{2+}$ through TRPV6, whereas at concentrations larger than $20 \mu \mathrm{M}$, they exert an inhibition [101], in agreement with older studies that found an inhibition of $\mathrm{Ca}^{2+}$ uptake by $\mathrm{Zn}^{2+}$ [164]. It has therefore been proposed that TRPV6 possesses two $\mathrm{Zn}^{2+}$-binding sites: an activating (high affinity) and an inhibitory (low affinity) binding sites. From the same TRP subfamily, TRPV2 channels activated with 2-APB are not sensitive to $100 \mu \mathrm{M} \mathrm{Zn}^{2+}$ [89].

The acidity-evoked proton current in TRPP3-expressing taste cells is strongly inhibited by $1 \mathrm{mM} \mathrm{Zn}^{2+}$ [22]. The "off response" of heterologously expressed TRPP3-PKD1L3 channels (see section "Transport of metal ions through TRPP channels"), on the other hand, was found to be unaffected by $\mathrm{Zn}^{2+}$ ions at the same concentration [83], again indicating that heteromultimeric TRPP3-PKD1L3 channels might not be identical to the transduction channels in acid-sensitive taste cells.

Inhibition of TRP channels by magnesium ions

$\mathrm{Mg}^{2+}$ is an important biological metal ion involved in many enzymatic reactions and playing crucial roles in cell signalling [230]. It influences ion transport mechanisms by regulating various ion channels, including some TRP channels (Fig. 2). Inhibition of TRP channels by intracellular $\mathrm{Mg}^{2+}$ was first demonstrated for TRPM7 [144]. Subsequently, $\mathrm{Mg}^{2+}$ was also shown to inhibit native currents which are now believed to be encoded by endogenously expressed TRPM7 channels [103, 104, 144, 168]. A controversy still exists as to whether TRPM7 channels are also regulated by $\mathrm{Mg}^{2+}$ complexed to nucleotides $[35,144]$ or whether the active species inhibiting the channel is free $\mathrm{Mg}^{2+}$ [103]. The closely related channel TRPM6 is equally inhibited by intracellular $\mathrm{Mg}^{2+}$ with an $\mathrm{IC}_{50}$ of $0.51 \mathrm{mM}$, and therefore at physiological concentrations of intracellular $\mathrm{Mg}^{2+}$ [217]. $\mathrm{Mg}^{2+}$ inhibition of TRPM6 is a very fast process occurring within tens of milliseconds as 


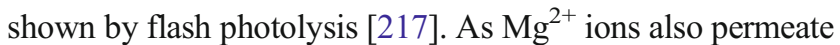
TRPM7 and TRPM6 (see section "Transport of metal ions through TRPM channels"), inhibition of these channels by intracellular $\mathrm{Mg}^{2+}$ constitutes a direct negative feedback loop. This is also true for TRPM3 channels, for which inhibition by intracellular $\mathrm{Mg}^{2+}$ in the physiological concentration range has been shown as well [157]. Interestingly, not only the divalent permeable splice variant TRPM $3 \alpha 2$ is inhibited by intracellular $\mathrm{Mg}^{2+}$, but also the splice variant TRPM $3 \alpha 1$ that conducts divalent ions only poorly [157]. The effects of intracellular $\mathrm{Mg}^{2+}$ have not yet been reported for heterologously expressed TRPM1 channels. However, for the transduction current in retinal ON-bipolar cells, which is believed to be mediated by TRPM1 channels [138], it has been reported that the transduction channels are partially inhibited by intracellular $\mathrm{Mg}^{2+}$ and that this inhibitory effect can be modulated by $\mathrm{PKC} \alpha$-dependent phosphorylation [170].

In TRPV5 and TRPV6 channels, intracellular $\mathrm{Mg}^{2+}$ induces a voltage-dependent block [216, 218] affecting outward currents, possibly by binding to the intracellular side of the ion-conducting pore. Intracellular $\mathrm{Mg}^{2+}$ ions thus contribute to the strong inward rectification of TRPV5 and TRPV6, although these channels also show intrinsic rectification in the absence of any divalent cations. In addition to the fast voltage-dependent inhibition by $\mathrm{Mg}^{2+}$, intracellular $\mathrm{Mg}^{2+}$ ions have been shown to induce a further, slow inactivation of TRPV5/6 channels [112, 216], which could be reversed by increasing $\mathrm{PIP}_{2}$ levels in the plasma membrane [112]. Voets et al. [216] also observed that $\mathrm{Mg}^{2+}$ ions block inward currents through TRPV5/6 when applied extracellularly. From the voltage dependence of this block, they inferred that inhibition was less severe at strongly negative potentials, which might be indicative of $\mathrm{Mg}^{2+}$ transport through the pore ("push through"). However, extreme voltages exceeding the physiological range were needed to observe this effect [216]. TRPV5 channels are also blocked by extracellular $\mathrm{Mg}^{2+}$, where the $\mathrm{IC}_{50}$ value varied with extracellular $\mathrm{Ca}^{2+}$ concentration [215]. A recent report indicates that TRPV3 channels are inhibited by $\mathrm{Mg}^{2+}$ from both the extracellular and intracellular side and that, accordingly, two different binding sites for $\mathrm{Mg}^{2+}$ on TRPV3 exist [125]. Interestingly, $\mathrm{Mg}^{2+}$ ions affect TRPV3 activity mainly by decreasing the single-channel conductance in a voltage-dependent manner. From the cytosolic side, $\mathrm{Mg}^{2+}$ ions reduce the outward currents more strongly then the inward currents through TRPV3; from the extracellular side, however, the inverse relationship was observed [125]. This observation indicates that $\mathrm{Mg}^{2+}$ ions are under the influence of the transmembrane electrical field. Consistent with this idea, mutational analysis indicated that positively charged amino acids at both sides of the ion-conducting pore (D641 for the extracellular site and E679 together with E682 for the intracellular site) are important for the inhibitory effect of $\mathrm{Mg}^{2+}$ ions [125]. Overall, the effects of $\mathrm{Mg}^{2+}$ on TRPV3 channels were of moderate magnitude $(<50 \%$ inhibition at physiological concentrations of extracellular $\mathrm{Mg}^{2+}$ ) [125]. Also, very recently, $100 \mathrm{mM} \mathrm{Mg}^{2+}$ was shown to inhibit TRPV1 channels from the cytosolic side in inside out patches [238]. Whether this inhibition by $\mathrm{Mg}^{2+}$ also occurs at physiologically realistic concentrations is not yet known. Interestingly, $\mathrm{Mg}^{2+}$ from the extracellular and intracellular side reduces the singlechannel conductance of TRPV1 [18, 238], reducing the apparent effect of activation of TRPV1 channels by extracellular $\mathrm{Mg}^{2+}$ (see section "Activation and potentiation of TRPV channels").

TRPA1 channels are also inhibited by intracellular $\mathrm{Mg}^{2+}$ ions, however, only at high concentrations $(>1.8 \mathrm{mM}$, [91, 227]). Nevertheless, since $\mathrm{Mg}^{2+}$ ions permeate TRPA1 channels, the effects of $\mathrm{Mg}^{2+}$ might occur under physiological conditions, as the intracellular concentration in the vicinity of the channels might be considerably higher than that in the bulk of the cytosol [227].

Equally, TRPC5 channels (but not TRPC1-TRPC5 heteromultimeric channels) are inhibited by intracellular $\mathrm{Mg}^{2+}$, with an $\mathrm{IC}_{50}$ of $457 \mu \mathrm{M}$ and therefore at physiologically relevant concentrations [159]. Interestingly, the inhibition by $\mathrm{Mg}^{2+}$ was attenuated in a mutant where one acidic amino acid (D633) at the intracellular side just distal to transmembrane domain 6 was mutated (to asparagine). This contrasts strongly with the situation in TRPV6 channels, where a negatively charged amino acid in the ion-conducting pore was found to be important for the inhibition by intracellular $\mathrm{Mg}^{2+}$ [216].

\section{Inhibition of TRP channels by toxic metal ions}

Toxic metal ions like $\mathrm{Cd}^{2+}$ and $\mathrm{Ni}^{2+}$ have long been used to block voltage-gated $\mathrm{Ca}^{2+}$ channels. Most TRP channels have, however, proved to be rather insensitive to these divalent cations, possibly reflecting their much broader ionic selectivity profile. As outlined above (section "Transport of metal ions through TRP channels"), some TRP channels are permeable also to these toxic substances or are even activated by them (see section "Activation and potentiation of TRP channels by metal ions"). Nevertheless, some TRP channels are also inhibited by these ions, as described below.

At very high concentrations (3-6 mM), $\mathrm{Ni}^{2+}$ was used to inhibit TRPC 3 channels activated by a store depletion protocol or by receptor activation $[107,245]$. Earlier, already, it was found that receptor-activated TRPC6 channels were inhibited by $\mathrm{Cd}^{2+}$ ions, with an $\mathrm{IC}_{50}$ of $253 \mu \mathrm{M}$ [81], which again represents a rather high value.

TRPM2 channels have been shown to be exceptionally resistant to inhibition by toxic divalent cations such as $\mathrm{Co}^{2+}$, $\mathrm{Ni}^{2+}, \mathrm{Cd}^{2+}$ as well as by essential metal ions like $\mathrm{Cu}^{2+}$ and $\mathrm{Zn}^{2+}$ even at the high concentration of $1 \mathrm{mM}$, as the observed 
inhibition was less than $5 \%$ [54]. Interestingly, however, TRPM2 channels are blocked in experimental settings by replacing extracellular $\mathrm{Ca}^{2+}$ with $\mathrm{Ba}^{2+}[45,63,128]$. It appears that $\mathrm{Ba}^{2+}$ cannot substitute for $\mathrm{Ca}^{2+}$, which is obligatory for activating TRPM2 channels [128].

TRPV1 channels in single-channel recordings are blocked by $\mathrm{Ba}^{2+}$ from the intracellular side with an $\mathrm{IC}_{50}$ of $0.89 \mathrm{mM}$ [237]. From the extracellular side, trivalent aluminium ions $\left(\mathrm{Al}^{3+}\right)$ inhibit at concentrations of $100 \mu \mathrm{M}$ or more TRPV1 channel activity [207]. TRPV4 (outward and inward) currents have been reported to be blocked by very high concentrations $(130 \mathrm{mM})$ of extracellular $\mathrm{Ba}^{2+}$ [115] despite the fact that others found that this cation also permeates through TRPV4 channels [191].

TRPV5 and TRPV6 channels have, as mentioned above, a high selectivity for $\mathrm{Ca}^{2+}$ and as such exhibit a much higher sensitivity to inhibition by other divalent cations. Accordingly, $\mathrm{Ca}^{2+}$ uptake through TRPV5 channels was found to be strongly inhibited by $100 \mu \mathrm{M}$ of $\mathrm{Pb}^{2+}, \mathrm{Cu}^{2+}$ and $\mathrm{Cd}^{2+}$, and to a lesser extent by $\mathrm{Co}^{2+}, \mathrm{Ni}^{2+}$ and $\mathrm{Zn}^{2+}[101,164]$. Electrophysiologically, the inhibition of TRPV 6 channels by $\mathrm{Cd}^{2+}$ was found to occur with an $\mathrm{IC}_{50}$ below $5 \mu \mathrm{M}[69,215]$.

\section{Changes in expression of TRP proteins induced by metal ions}

So far, only few studies have provided data suggesting that TRP channel expression is regulated by metal ions. The data available cover a limited number of elements: lithium, gadolinium, cobalt and platinum. The published results are summarized in this section and in Table 3.

Changes in TRP channel expression induced by lithium

$\mathrm{Li}^{+}$is a metal ion used for decades in the treatment of some mood disorders [184]. Interestingly, it seems to regulate the expression of TRPC3 channels. Indeed, $\mathrm{Li}^{+}$chronically applied to human B lymphoblasts (for 7 days at a therapeutically relevant concentration) diminishes TRPC3 expression [5]. This $\mathrm{Li}^{+}$-dependent regulation is specifically observed in $\mathrm{B}$

Table 3 TRP proteins showing augmented expression after exposure to metal ions

\begin{tabular}{lll}
\hline Channel & Metal ions & References \\
\hline TRPA1 & $\mathrm{Pt}^{2+}$ & {$[198]$} \\
TRPC6 & $\mathrm{Co}^{2+}, \mathrm{Gd}^{3+}$ & {$[25,196]$} \\
TRPM8 & $\mathrm{Pt}^{2+}$ & {$[48,198]$ but see $[148]$} \\
TRPV1 & $\mathrm{Pt}^{2+}$ & {$[140]$} \\
TRPV2 & $\mathrm{Pt}^{2+}$ & {$[74]$} \\
\hline
\end{tabular}

lymphoblasts from patients suffering from bipolar disorder but not in B lymphoblasts from healthy control subjects. Moreover, this regulation by $\mathrm{Li}^{+}$seems to affect TRPC3 channels with some specificity because the expression of TRPC4 is not modified [5].

Changes in TRP channels expression induced by gadolinium or cobalt

A recent report suggested that in rat neonatal ventricular myocytes, $\mathrm{Gd}^{3+}$, applied as a solution of $\mathrm{GdCl}_{3}$, enhances the expression of TRPC 6 channels via the activation of the $\mathrm{Ca}^{2+}$-sensing receptor [196].

$\mathrm{Co}^{2+}$ ions have largely been used to mimic hypoxic conditions. Of interest, in some adult brain tumours, solutions of $\mathrm{CoCl}_{2}$ augment the basal concentration of $\mathrm{Ca}^{2+}$ by causing an overexpression of TRPC6 channels (mRNA, protein level). This effect is controlled by Notch1 [25].

Changes in expression of TRP channels induced by platinum compounds

In addition to their reported effects on the activity of TRPA1 and TRPV1 channels (see sections "Activation and potentiation of TRPA channels" and "Activation and potentiation of TRPV channels"), $\mathrm{Pt}^{2+}$-containing substances (cisplatin, oxaliplatin) have also been shown to affect TRP channel expression. Cisplatin augments TRPV1 expression in the organ of Corti, and this process may play a role in cisplatin-induced cochlear cell loss [142]. Up-regulation of TRPV1 expression was dependent on ROS generation by NOX-3, as it could be suppressed by scavenging ROS with lipoic acid, pharmacologically inhibiting NOX-3 or by siRNA-mediated knockdown of this enzyme [140, 142]. Interestingly, cisplatininduced TRPV1-dependent $\mathrm{Ca}^{2+}$ influx seems to induce a positive feedback loop by activating and inducing NOX-3 and STAT-1, as NOX-3 in turn augments TRPV1 expression and activity [140, 141]. The STAT-1-induced inflammatory processes finally cause cochlear cell death and ultimately lead to hearing loss.

The mRNA levels of TRPM8 were found to be increased in oxaliplatin-injected animals [48]. Accordingly, the cold allodynia induced by oxaliplatin could be prevented by capsazepine, a blocker of TRPM8 (and TRPV1) channels, but not by 5 '-iodoresiniferatoxin, a selective TRPV1 blocker. From these data, Gauchan et al. concluded that the cold allodynia caused by oxaliplatin was partly due to the increased expression of TRPM8 channels in primary afferents [48]. However, this view has not been universally accepted. Knowlton et al. [99] found that TRPM8 was necessary for oxaliplatin-induced cold allodynia, as TRPM8-deficient mice did not develop this condition. However, acute blockade of TRPM8 channels (by PMBC; 1-phenylethyl-4-(benzyloxy)- 
3-methoxybenzyl(2-aminoethyl)carbamate) failed to ameliorate the oxaliplatin-induced cold allodynia [99]. In addition, Ta et al. [198] showed that treatment of mice with cisplatin or oxaliplatin up-regulates mRNA levels of TRPV1, TRPA1 and, only to a lesser extent, the mRNA levels of TRPM8. These authors provided further evidence that the up-regulation of TRPV1 expression seen at the transcriptional level is involved in the heat hyperalgesia observed in mice suffering from cisplatin-induced neuropathy. A Japanese herbal drug (gosha-jinki-gan) was found to reduce oxaliplatin-induced cold hyperalgesia and also the expression of TRPM8 and TRPA1 in rat DRG cells [93]. Another study found that the intraperitoneal injection of cisplatin in rats up-regulates the expression of TRPV2 in DRG cells, but not the expression of TRPV1, as assayed immuno-histochemically [74]. A still different picture was presented by Nassini et al. [148]. As explained above (section "Activation and potentiation of TRPA channels"), these authors favour a model in which TRPA1 is activated by GSH-sensitive compounds produced during exposure to $\mathrm{P}^{2+}$-containing compounds. A transient increase in mRNA-encoding TRPA1 was also found after treatment with oxaliplatin, but the authors concluded that it is too short-lived to explain the allodynia that persisted for days [148]. Finally, it should be noted that ion channels other than TRP channels have also been implicated in cisplatin- or oxaliplatin-induced hyperalgesia [36, 74].

In summary, the currently available data about the anticancer drugs on the expression of TRP channels are inconsistent and contradictory. Clearly, more experiments are needed to identify whether changes in TRP channel expression are functionally important and to disentangle the effects of increased channel expression and regulation of channel activity. Furthermore, the mechanism by which $\mathrm{Pt}^{2+}$-based drugs influence TRP channel expression is still entirely unclear. Accordingly, it is not understood why different $\mathrm{Pt}^{2+}$-containing drugs have different effects on TRP channels and what the precise role of the different moieties of these compounds is.

\section{Conclusions}

A large number of proteins dedicated to the transport of essential biological metal ions have been characterized, among them many ion channels. Most of the data available on the transport of trace metal ions by membrane channels concern voltage-gated $\mathrm{Ca}^{2+}$ channels and ionotropic glutamate (AMPA and NMDA) channels. However, recent findings have attracted attention to TRP proteins as new actors in trace metal ion transport. They form a diverse superfamily of cation channels widely expressed and fulfil various biological roles. Besides their well-documented function of delivering $\mathrm{Ca}^{2+}$ and $\mathrm{Na}^{+}$ions to the cytosolic compartment (and depolarizing the cellular membrane potential in the process), a growing number of experimental observations indicate a role of TRP channels in the transport of biologically relevant and toxic trace metal ions.

However, as we have attempted to highlight in this review, our knowledge of the interaction between TRP channels and metal ions is still rudimentary. Strikingly, for many TRP channels, it is unknown whether and to what extent they are permeable to trace metal ions. Even less is known about their permeability to these cations under physiological conditions. Since these questions can be addressed by standard experimental techniques, it is hoped that the present review stimulates research in order to fill in these obvious gaps in our knowledge. Such research would be of high relevance because metal ions are not only necessary for all living cells, but some of them are also environmental pollutants. Understanding the molecular mechanisms participating in trace metal ion uptake and delivery into cells is thus of crucial importance.

It is important to underscore the fact that metal ions exert subtle and complex effects on TRP proteins, ranging from short-term (permeation, block and inhibition) to long-lasting responses (regulation of expression). In general, studies investigating the regulation of TRP channel expression have been scarce, and it is therefore not surprising that the long-term effects of metal ions on TRP channel activity have not been explored in any detail. This field also deserves attention in future studies. It thus appears that the complex relationships between trace metal ions and TRP channels are in need of further research on many levels, ranging from fast biophysical processes (like permeation) to the long-term regulation of ion channel protein expression. Important new discoveries with considerable clinical implications can be expected in this emerging area of research.

Acknowledgments We thank Drs Christian Halaszovich and Sandeep Dembla for critically reading the manuscript. Supported by grants from SFB 593 (to J.O.) and National Institutes of Health (HD058577 and ES01678; to K.K.).

Open Access This article is distributed under the terms of the Creative Commons Attribution License which permits any use, distribution, and reproduction in any medium, provided the original author(s) and the source are credited.

\section{References}

1. Aarts M, Iihara K, Wei W-L, Xiong Z-G, Arundine M, Cerwinski W, MacDonald JF, Tymianski M (2003) A key role for TRPM7 channels in anoxic neuronal death. Cell 115(7):863-877

2. Ahern GP, Brooks IM, Miyares RL, X-b W (2005) Extracellular cations sensitize and gate capsaicin receptor TRPV1 modulating pain signaling. J Neurosci 25(21):5109-5116

3. Altarescu G, Sun M, Moore DF, Smith JA, Wiggs EA, Solomon BI, Patronas NJ, Frei KP, Gupta S, Kaneski CR, Quarrell OW, 
Slaugenhaupt SA, Goldin E, Schiffmann R (2002) The neurogenetics of mucolipidosis type IV. Neurology 59(3):306-313

4. Andersson DA, Gentry C, Moss S, Bevan S (2009) Clioquinol and pyrithione activate TRPA1 by increasing intracellular $\mathrm{Zn}^{2+}$. Proc Natl Acad Sci U S A 106(20):8374-8379

5. Andreopoulos S, Wasserman M, Woo K, Li PP, Warsh JJ (2004) Chronic lithium treatment of B lymphoblasts from bipolar disorder patients reduces transient receptor potential channel 3 levels. Pharmacogenomics J 4(6):365-373

6. Anyatonwu GI, Ehrlich BE (2005) Organic cation permeation through the channel formed by polycystin-2. J Biol Chem 280(33):29488-29493

7. Bai C-X, Giamarchi A, Rodat-Despoix L, Padilla F, Downs T, Tsiokas L, Delmas P (2008) Formation of a new receptor-operated channel by heteromeric assembly of TRPP2 and TRPC1 subunits. EMBO Rep 9(5):472-479

8. Banke TG (2011) The dilated TRPA1 channel pore state is blocked by amiloride and analogues. Brain Res 1381:21-30

9. Banke TG, Chaplan SR, Wickenden AD (2010) Dynamic changes in the TRPA 1 selectivity filter lead to progressive but reversible pore dilation. Am J Physiol Cell Physiol 298(6):C1457-C1468

10. Bassi MT, Manzoni M, Monti E, Pizzo MT, Ballabio A, Borsani G (2000) Cloning of the gene encoding a novel integral membrane protein, mucolipidin-and identification of the two major founder mutations causing mucolipidosis type IV. Am J Hum Genet 67(5): $1110-1120$

11. Bautista DM, Pellegrino M, Tsunozaki M (2013) TRPA1: a gatekeeper for inflammation. Annu Rev Physiol 75:181-200

12. Becker D, Blase C, Bereiter-Hahn J, Jendrach M (2005) TRPV4 exhibits a functional role in cell-volume regulation. J Cell Sci 118(Pt 11):2435-2440

13. Binshtok AM, Bean BP, Woolf CJ (2007) Inhibition of nociceptors by TRPV1-mediated entry of impermeant sodium channel blockers. Nature 449(7162):607-610

14. Bobkov YV, Corey EA, Ache BW (2011) The pore properties of human nociceptor channel TRPA1 evaluated in single channel recordings. Biochim Biophys Acta 1808(4):1120-1128

15. Boulay G, Zhu X, Peyton M, Jiang M, Hurst R, Stefani E, Birnbaumer L (1997) Cloning and expression of a novel mammalian homolog of Drosophila transient receptor potential (Trp) involved in calcium entry secondary to activation of receptors coupled by the Gq class of G protein. J Biol Chem 272(47): 29672-29680

16. Bouron A, Oberwinkler J (2014) Contribution of calciumconducting channels to the transport of zinc ions. Pflugers Arch 466(3):381-387

17. Bowen CV, DeBay D, Ewart HS, Gallant P, Gormley S, Ilenchuk TT, Iqbal U, Lutes T, Martina M, Mealing G, Merkley N, Sperker S, Moreno MJ, Rice C, Syvitski RT, Stewart JM (2013) In vivo detection of human TRPV6-rich tumors with anti-cancer peptides derived from soricidin. PLoS One 8(3): 58866

18. Cao X, Ma L, Yang F, Wang K, Zheng J (2014) Divalent cations potentiate TRPV1 channel by lowering the heat activation threshold. J Gen Physiol 143(1):75-90

19. Carvacho I, Lee HC, Fissore RA, Clapham DE (2013) TRPV3 channels mediate strontium-induced mouse-egg activation. Cell Rep 5(5):1375-1386

20. Caterina MJ, Rosen TA, Tominaga M, Brake AJ, Julius D (1999) A capsaicin-receptor homologue with a high threshold for noxious heat. Nature 398(6726):436-441

21. Caterina MJ, Schumacher MA, Tominaga M, Rosen TA, Levine JD, Julius D (1997) The capsaicin receptor: a heat-activated ion channel in the pain pathway. Nature 389(6653):816-824

22. Chang RB, Waters H, Liman ER (2010) A proton current drives action potentials in genetically identified sour taste cells. Proc Natl Acad Sci U S A 107(51):22320-22325
23. Chen XZ, Vassilev PM, Basora N, Peng JB, Nomura H, Segal Y, Brown EM, Reeders ST, Hediger MA, Zhou J (1999) Polycystin-L is a calcium-regulated cation channel permeable to calcium ions. Nature 401(6751):383-386

24. Chevallet M, Jarvis L, Harel H, Luche S, Degot S, Chapuis V, Boulay G, Rabilloud T, Bouron A (2014) Functional consequences of the over-expression of TRPC6 channels in HEK cells: impact on the homeostasis of zinc. Metallomics 6(7):1269-1276

25. Chigurupati S, Venkataraman R, Barrera D, Naganathan A, Madan M, Paul L, Pattisapu JV, Kyriazis GA, Sugaya K, Bushnev S, Lathia JD, Rich JN, Chan SL (2010) Receptor channel TRPC6 is a key mediator of Notch-driven glioblastoma growth and invasiveness. Cancer Res 70(1):418-427

26. H-h C, Neuhausser WM, Julius D (2004) The super-cooling agent icilin reveals a mechanism of coincidence detection by a temperature-sensitive TRP channel. Neuron 43(6):859-869

27. Chubanov V, Waldegger S, Mederos y Schnitzler M, Vitzthum H, Sassen MC, Seyberth HW, Konrad M, Gudermann T (2004) Disruption of TRPM6/TRPM7 complex formation by a mutation in the TRPM6 gene causes hypomagnesemia with secondary hypocalcemia. Proc Natl Acad Sci U S A 101(9):2894-2899

28. Chung M-K, Güler AD, Caterina MJ (2008) TRPV1 shows dynamic ionic selectivity during agonist stimulation. Nat Neurosci 11(5): 555-564

29. Coblentz J, St Croix C, Kiselyov K (2014) Loss of TRPML1 promotes production of reactive oxygen species: is oxidative damage a factor in mucolipidosis type IV? Biochem J 457(2):361-368

30. Courjaret R, Hubrack S, Daalis A, Dib M, Machaca K (2013) The Xenopus TRPV6 homolog encodes a $\mathrm{Mg}(2+)$-permeant channel that is inhibited by interaction with TRPC1. J Cell Physiol 228(12): 2386-2398

31. Davies PA, Wang W, Hales TG, Kirkness EF (2003) A novel class of ligand-gated ion channel is activated by $\mathrm{Zn}^{2+}$. J Biol Chem 278(2):712-717

32. DeCaen PG, Delling M, Vien TN, Clapham DE (2013) Direct recording and molecular identification of the calcium channel of primary cilia. Nature 504(7479):315-318

33. Delling M, DeCaen PG, Doerner JF, Febvay S, Clapham DE (2013) Primary cilia are specialized calcium signalling organelles. Nature 504(7479):311-314

34. Delmas P, Nauli SM, Li X, Coste B, Osorio N, Crest M, Brown DA, Zhou J (2004) Gating of the polycystin ion channel signaling complex in neurons and kidney cells. FASEB J 18(6):740-742

35. Demeuse P, Penner R, Fleig A (2006) TRPM7 channel is regulated by magnesium nucleotides via its kinase domain. J Gen Physiol 127(4):421-434

36. Descoeur J, Pereira V, Pizzoccaro A, Francois A, Ling B, Maffre V, Couette B, Busserolles J, Courteix C, Noel J, Lazdunski M, Eschalier A, Authier N, Bourinet E (2011) Oxaliplatin-induced cold hypersensitivity is due to remodelling of ion channel expression in nociceptors. EMBO Mol Med 3(5):266-278

37. Dietrich A, Gudermann T (2007) TRPC6. Handb Exp Pharmacol 179:125-141

38. Dietrich A, Mederos y Schnitzler M, Emmel J, Kalwa H, Hofmann T, Gudermann T (2003) N-linked protein glycosylation is a major determinant for basal TRPC3 and TRPC6 channel activity. J Biol Chem 278(48):47842-47852

39. Dong X-P, Cheng X, Mills E, Delling M, Wang F, Kurz T, Xu H (2008) The type IV mucolipidosis-associated protein TRPML1 is an endolysosomal iron release channel. Nature 455(7215):992-996

40. X-p D, Wang X, Shen D, Chen S, Liu M, Wang Y, Mills E, Cheng X, Delling M, Xu H (2009) Activating mutations of the TRPML1 channel revealed by proline-scanning mutagenesis. J Biol Chem 284(46):32040-32052

41. Dong X-P, Wang X, Xu H (2010) TRP channels of intracellular membranes. J Neurochem 113(2):313-328 
42. Drews A, Mohr F, Rizun O, Wagner TFJ, Dembla S, Rudolph S, Lambert S, Konrad M, Philipp SE, Behrendt M, MarchaisOberwinkler S, Covey DF, Oberwinkler J (2014) Structural requirements of steroidal agonists of transient receptor potential melastatin 3 (TRPM3) cation channels. Br J Pharmacol 171(4):1019-1032

43. Eichelsdoerfer JL, Evans JA, Slaugenhaupt SA, Cuajungco MP (2010) Zinc dyshomeostasis is linked with the loss of mucolipidosis IV-associated TRPML1 ion channel. J Biol Chem 285(45):34304 34308

44. Elinder F, Arhem P (2003) Metal ion effects on ion channel gating. Q Rev Biophys 36(4):373-427

45. Fonfria E, Marshall ICB, Benham CD, Boyfield I, Brown JD, Hill K, Hughes JP, Skaper SD, McNulty S (2004) TRPM2 channel opening in response to oxidative stress is dependent on activation of poly(ADP-ribose) polymerase. $\mathrm{Br}$ J Pharmacol 143(1):186-192

46. Frühwald J, Camacho Londoño J, Dembla S, Mannebach S, Lis A, Drews A, Wissenbach U, Oberwinkler J, Philipp SE (2012) Alternative splicing of a protein domain indispensable for function of transient receptor potential melastatin 3 (TRPM3) ion channels. J Biol Chem 287(44):36663-36672

47. García-Martínez C, Morenilla-Palao C, Planells-Cases R, Merino JM, Ferrer-Montiel A (2000) Identification of an aspartic residue in the P-loop of the vanilloid receptor that modulates pore properties. J Biol Chem 275(42):32552-32558

48. Gauchan P, Andoh T, Kato A, Kuraishi Y (2009) Involvement of increased expression of transient receptor potential melastatin 8 in oxaliplatin-induced cold allodynia in mice. Neurosci Lett 458(2):93-95

49. Georgiev P, Okkenhaug H, Drews A, Wright D, Lambert S, Flick M, Carta V, Martel C, Oberwinkler J, Raghu P (2010) TRPM channels mediate zinc homeostasis and cellular growth during Drosophila larval development. Cell Metab 12(4):386-397

50. Gibon J, Tu P, Bohic S, Richaud P, Arnaud J, Zhu M, Boulay G, Bouron A (2011) The over-expression of TRPC6 channels in HEK293 cells favours the intracellular accumulation of zinc. Biochim Biophys Acta 1808(12):2807-2818

51. González-Perrett S, Kim K, Ibarra C, Damiano AE, Zotta E, Batelli M, Harris PC, Reisin IL, Arnaout MA, Cantiello HF (2001) Polycystin-2, the protein mutated in autosomal dominant polycystic kidney disease (ADPKD), is a $\mathrm{Ca}^{2+}$-permeable nonselective cation channel. Proc Natl Acad Sci U S A 98(3):1182-1187

52. Greene LA, Tischler AS (1976) Establishment of a noradrenergic clonal line of rat adrenal pheochromocytoma cells which respond to nerve growth factor. Proc Natl Acad Sci U S A 73(7):2424-2428

53. Grimm C, Kraft R, Sauerbruch S, Schultz G, Harteneck C (2003) Molecular and functional characterization of the melastatin-related cation channel TRPM3. J Biol Chem 278(24):21493-21501

54. Grupe M, Myers G, Penner R, Fleig A (2010) Activation of storeoperated I(CRAC) by hydrogen peroxide. Cell Calcium 48(1):1-9

55. Gu Q (1985) Lin R-L (2010) Heavy metals zinc, cadmium, and copper stimulate pulmonary sensory neurons via direct activation of TRPA1. J Appl Physiol 108(4):891-897

56. Guo Z, Grimm C, Becker L, Ricci AJ, Heller S (2013) A novel ion channel formed by interaction of TRPML3 with TRPV5. PLoS One 8(2):e58174

57. Hagiwara S, Byerly L (1981) Calcium channel. Annu Rev Neurosci 4:69-125

58. Halaszovich CR, Zitt C, Jüngling E, Lückhoff A (2000) Inhibition of TRP3 channels by lanthanides. Block from the cytosolic side of the plasma membrane. J Biol Chem 275(48):37423-37428

59. Hanaoka K, Qian F, Boletta A, Bhunia AK, Piontek K, Tsiokas L, Sukhatme VP, Guggino WB, Germino GG (2000) Co-assembly of polycystin-1 and -2 produces unique cation-permeable currents. Nature 408(6815):990-994
60. Hara Y, Wakamori M, Ishii M, Maeno E, Nishida M, Yoshida T, Yamada H, Shimizu S, Mori E, Kudoh J, Shimizu N, Kurose H, Okada Y, Imoto K, Mori Y (2002) LTRPC2 $\mathrm{Ca}^{2+}$-permeable channel activated by changes in redox status confers susceptibility to cell death. Mol Cell 9(1):163-173

61. Hardie RC, Minke B (1992) The trp gene is essential for a lightactivated $\mathrm{Ca}^{2+}$ channel in Drosophila photoreceptors. Neuron 8(4): 643-651

62. Heilig EA, Thompson KJ, Molina RM, Ivanov AR, Brain JD, Wessling-Resnick M (2006) Manganese and iron transport across pulmonary epithelium. Am J Physiol Lung Cell Mol Physiol 290(6):L1247-L1259

63. Hill K, Tigue NJ, Kelsell RE, Benham CD, McNulty S, Schaefer M, Randall AD (2006) Characterisation of recombinant rat TRPM2 and a TRPM2-like conductance in cultured rat striatal neurones. Neuropharmacology 50(1):89-97

64. Hille B (2001) Ion channels of excitable membranes. Sinauer, Sunderland (MA)

65. Hinkle PM, Shanshala ED 2nd, Nelson EJ (1992) Measurement of intracellular cadmium with fluorescent dyes. Further evidence for the role of calcium channels in cadmium uptake. J Biol Chem 267(35):25553-25559

66. Hochstrate P (1989) Lanthanum mimicks the trp photoreceptor mutant of Drosophila in the blowfly Calliphora. J Comp Physiol A 166(2):179-187

67. Hoenderop JG, van der Kemp AW, Hartog A, van de Graaf SF, van Os CH, Willems PH, Bindels RJ (1999) Molecular identification of the apical $\mathrm{Ca}^{2+}$ channel in 1,25-dihydroxyvitamin D3-responsive epithelia. J Biol Chem 274(13):8375-8378

68. Hoenderop JG, Vennekens R, Müller D, Prenen J, Droogmans G, Bindels RJ, Nilius B (2001) Function and expression of the epithelial $\mathrm{Ca}(2+)$ channel family: comparison of mammalian $\mathrm{ECaC} 1$ and 2. J Physiol 537(Pt 3):747-761

69. Hoenderop JGJ, Voets T, Hoefs S, Weidema F, Prenen J, Nilius B, Bindels RJM (2003) Homo- and heterotetrameric architecture of the epithelial $\mathrm{Ca}^{2+}$ channels TRPV5 and TRPV6. EMBO J 22(4): 776-785

70. Hoffmann A, Grimm C, Kraft R, Goldbaum O, Wrede A, Nolte C, Hanisch U-K, Richter-Landsberg C, Brück W, Kettenmann H, Harteneck C (2010) TRPM3 is expressed in sphingosineresponsive myelinating oligodendrocytes. J Neurochem 114(3): 654-665

71. Hofmann T, Chubanov V, Chen X, Dietz AS, Gudermann T, Montell C (2010) Drosophila TRPM channel is essential for the control of extracellular magnesium levels. PLoS One 5(5):e10519

72. Hofmann T, Chubanov V, Gudermann T, Montell C (2003) TRPM5 is a voltage-modulated and $\mathrm{Ca}(2+)$-activated monovalent selective cation channel. Curr Biol 13(13):1153-1158

73. Hofmann T, Obukhov AG, Schaefer M, Harteneck C, Gudermann T, Schultz G (1999) Direct activation of human TRPC6 and TRPC3 channels by diacylglycerol. Nature 397(6716):259-263

74. Hori K, Ozaki N, Suzuki S, Sugiura Y (2010) Upregulations of P2X(3) and ASIC3 involve in hyperalgesia induced by cisplatin administration in rats. Pain 149(2):393-405

75. Horio N, Yoshida R, Yasumatsu K, Yanagawa Y, Ishimaru Y, Matsunami H, Ninomiya Y (2011) Sour taste responses in mice lacking PKD channels. PLoS One 6(5):e20007

76. Hou S, Vigeland LE, Zhang G, Xu R, Li M, Heinemann SH, Hoshi $\mathrm{T}(2010) \mathrm{Zn}^{2+}$ activates large conductance $\mathrm{Ca}^{2+}$-activated $\mathrm{K}^{+}$channel via an intracellular domain. J Biol Chem 285(9):6434-6442

77. Hu H, Bandell M, Petrus MJ, Zhu MX, Patapoutian A (2009) Zinc activates damage-sensing TRPA1 ion channels. Nat Chem Biol 5(3): $183-190$

78. Huang AL, Chen X, Hoon MA, Chandrashekar J, Guo W, Tränkner D, Ryba NJP, Zuker CS (2006) The cells and logic for mammalian sour taste detection. Nature 442(7105):934-938 
79. Inada H, Kawabata F, Ishimaru Y, Fushiki T, Matsunami H, Tominaga M (2008) Off-response property of an acid-activated cation channel complex PKD1L3-PKD2L1. EMBO Rep 9(7): 690-697

80. Inoue K, Branigan D, Xiong Z-G (2010) Zinc-induced neurotoxicity mediated by transient receptor potential melastatin 7 channels. J Biol Chem 285(10):7430-7439

81. Inoue R, Okada T, Onoue H, Hara Y, Shimizu S, Naitoh S, Ito Y, Mori Y (2001) The transient receptor potential protein homologue TRP6 is the essential component of vascular $\alpha_{1}$-adrenoceptor-activated $\mathrm{Ca}^{2+}$-permeable cation channel. Circ Res 88(3):325-332

82. Ishida Y, Ugawa S, Ueda T, Murakami S, Shimada S (2002) Vanilloid receptor subtype-1 (VR1) is specifically localized to taste papillae. Brain Res Mol Brain Res 107(1):17-22

83. Ishii S, Kurokawa A, Kishi M, Yamagami K, Okada S, Ishimaru Y, Misaka T (2012) The response of PKD1L3/PKD2L1 to acid stimuli is inhibited by capsaicin and its pungent analogs. FEBS J 279(10): $1857-1870$

84. Ishimaru $Y$, Inada $H$, Kubota $M$, Zhuang $H$, Tominaga $M$, Matsunami H (2006) Transient receptor potential family members PKD1L3 and PKD2L1 form a candidate sour taste receptor. Proc Natl Acad Sci U S A 103(33):12569-12574

85. Jiang J, Li M, Yue L (2005) Potentiation of TRPM7 inward currents by protons. J Gen Physiol 126(2):137-150

86. Jin J, Desai BN, Navarro B, Donovan A, Andrews NC, Clapham DE (2008) Deletion of Trpm7 disrupts embryonic development and thymopoiesis without altering $\mathrm{Mg}^{2+}$ homeostasis. Science 322(5902):756-760

87. Jordt SE, Tominaga M, Julius D (2000) Acid potentiation of the capsaicin receptor determined by a key extracellular site. Proc Natl Acad Sci U S A 97(14):8134-8139

88. Jung S, Mühle A, Schaefer M, Strotmann R, Schultz G, Plant TD (2003) Lanthanides potentiate TRPC5 currents by an action at extracellular sites close to the pore mouth. J Biol Chem 278(6): 3562-3571

89. Juvin V, Penna A, Chemin J, Lin Y-L, Rassendren F-A (2007) Pharmacological characterization and molecular determinants of the activation of transient receptor potential V2 channel orthologs by 2-aminoethoxydiphenyl borate. Mol Pharmacol 72(5):1258 1268

90. Kamouchi M, Philipp S, Flockerzi V, Wissenbach U, Mamin A, Raeymaekers L, Eggermont J, Droogmans G, Nilius B (1999) Properties of heterologously expressed hTRP3 channels in bovine pulmonary artery endothelial cells. J Physiol 518(Pt 2):345-358

91. Karashima Y, Prenen J, Meseguer V, Owsianik G, Voets T, Nilius B (2008) Modulation of the transient receptor potential channel TRPA1 by phosphatidylinositol 4,5-biphosphate manipulators. Pflugers Arch 457(1):77-89

92. Karashima Y, Prenen J, Talavera K, Janssens A, Voets T, Nilius B (2010) Agonist-induced changes in $\mathrm{Ca}(2+)$ permeation through the nociceptor cation channel TRPA1. Biophys J 98(5):773-783

93. Kato Y, Tateai Y, Ohkubo M, Saito Y, Amagai S-Y, Kimura Y-S, Iimura N, Okada M, Matsumoto A, Mano Y, Hirosawa I, Ohuchi K, Tajima M, Asahi M, Kotaki H, Yamada H (2014) Gosha-jinki-gan reduced oxaliplatin-induced hypersensitivity to cold sensation and its effect would be related to suppression of the expression of TRPM8 and TRPA1 in rats. Anticancer Drugs 25(1):39-43

94. Kawaguchi H, Yamanaka A, Uchida K, Shibasaki K, Sokabe T, Maruyama Y, Yanagawa Y, Murakami S, Tominaga M (2010) Activation of polycystic kidney disease-2-like 1 (PKD2L1)PKD1L3 complex by acid in mouse taste cells. J Biol Chem 285(23):17277-17281

95. Kerschbaum HH, Kozak JA, Cahalan MD (2003) Polyvalent cations as permeant probes of MIC and TRPM7 pores. Biophys J 84(4):2293-2305
96. Kim HJ, Li Q, Tjon-Kon-Sang S, So I, Kiselyov K, Soyombo AA, Muallem S (2008) A novel mode of TRPML3 regulation by extracytosolic $\mathrm{pH}$ absent in the varitint-waddler phenotype. EMBO J 27(8):1197-1205

97. Kiss T, Osipenko O (1994) Metal ion-induced permeability changes in cell membranes: a minireview. Cell Mol Neurobiol 14(6):781789

98. Kiss T, Osipenko ON (1994) Toxic effects of heavy metals on ionic channels. Pharmacol Rev 46(3):245-267

99. Knowlton WM, Daniels RL, Palkar R, McCoy DD, McKemy DD (2011) Pharmacological blockade of TRPM8 ion channels alters cold and cold pain responses in mice. PLoS One 6(9):e25894

100. Koulen P, Cai Y, Geng L, Maeda Y, Nishimura S, Witzgall R, Ehrlich BE, Somlo S (2002) Polycystin-2 is an intracellular calcium release channel. Nat Cell Biol 4(3):191-197

101. Kovacs G, Danko T, Bergeron MJ, Balazs B, Suzuki Y, Zsembery A, Hediger MA (2011) Heavy metal cations permeate the TRPV6 epithelial cation channel. Cell Calcium 49(1):43-55

102. Kovacs G, Montalbetti N, Franz M-C, Graeter S, Simonin A, Hediger MA (2013) Human TRPV5 and TRPV6: key players in cadmium and zinc toxicity. Cell Calcium 54(4):276-286

103. Kozak JA, Cahalan MD (2003) MIC channels are inhibited by internal divalent cations but not ATP. Biophys J 84(2 Pt 1):922-927

104. Kozak JA, Kerschbaum HH, Cahalan MD (2002) Distinct properties of CRAC and MIC channels in RBL cells. J Gen Physiol 120(2):221-235

105. Kraft R, Grimm C, Grosse K, Hoffmann A, Sauerbruch S, Kettenmann H, Schultz G, Harteneck C (2004) Hydrogen peroxide and ADP-ribose induce TRPM2-mediated calcium influx and cation currents in microglia. Am J Physiol Cell Physiol 286(1):C129 C137

106. Kukic I, Lee JK, Coblentz J, Kelleher SL, Kiselyov K (2013) Zincdependent lysosomal enlargement in TRPML1-deficient cells involves MTF-1 transcription factor and ZnT4 (Slc30a4) transporter. Biochem J 451(2):155-163

107. Kwan H-Y, Huang Y, Yao X (2004) Regulation of canonical transient receptor potential isoform 3 (TRPC3) channel by protein kinase G. Proc Natl Acad Sci U S A 101(8):2625-2630

108. Lambert S, Drews A, Rizun O, Wagner TFJ, Lis A, Mannebach S, Plant S, Portz M, Meissner M, Philipp SE, Oberwinkler J (2011) Transient receptor potential melastatin 1 (TRPM1) is an ionconducting plasma membrane channel inhibited by zinc ions. $\mathrm{J}$ Biol Chem 286(14):12221-12233

109. LaPlante JM, Falardeau J, Sun M, Kanazirska M, Brown EM, Slaugenhaupt SA, Vassilev PM (2002) Identification and characterization of the single channel function of human mucolipin-1 implicated in mucolipidosis type IV, a disorder affecting the lysosomal pathway. FEBS Lett 532(1-2):183-187

110. Launay P, Fleig A, Perraud AL, Scharenberg AM, Penner R, Kinet JP (2002) TRPM4 is a $\mathrm{Ca}^{2+}$-activated nonselective cation channel mediating cell membrane depolarization. Cell 109(3):397-407

111. Lechner SG, Markworth S, Poole K, Smith ESJ, Lapatsina L, Frahm S, May M, Pischke S, Suzuki M, Ibañez-Tallon I, Luft FC, Jordan J, Lewin GR (2011) The molecular and cellular identity of peripheral osmoreceptors. Neuron 69(2):332-344

112. Lee J, Cha S-K, Sun T-J, Huang C-L (2005) PIP2 activates TRPV5 and releases its inhibition by intracellular $\mathrm{Mg}^{2+}$. $\mathrm{J}$ Gen Physiol 126(5):439-451

113. Lee N, Chen J, Sun L, Wu S, Gray KR, Rich A, Huang M, Lin J-H, Feder JN, Janovitz EB, Levesque PC, Blanar MA (2003) Expression and characterization of human transient receptor potential melastatin 3 (hTRPM3). J Biol Chem 278(23):20890-20897

114. Leffler A, Linte RM, Nau C, Reeh P, Babes A (2007) A highthreshold heat-activated channel in cultured rat dorsal root ganglion 
neurons resembles TRPV2 and is blocked by gadolinium. Eur $\mathrm{J}$ Neurosci 26(1):12-22

115. Lei L, Cao X, Yang F, Shi D-J, Tang Y-Q, Zheng J, Wang K (2013) A TRPV4 channel C-terminal folding recognition domain critical for trafficking and function. J Biol Chem 288(15):10427-10439

116. Lev S, Minke B (2010) Constitutive activity of TRP channels methods for measuring the activity and its outcome. Methods Enzymol 484:591-612

117. Li M, Du J, Jiang J, Ratzan W, Su L-T, Runnels LW, Yue L (2007) Molecular determinants of $\mathrm{Mg}^{2+}$ and $\mathrm{Ca}^{2+}$ permeability and $\mathrm{pH}$ sensitivity in TRPM6 and TRPM7. J Biol Chem 282(35):2581725830

118. Li M, Jiang J, Yue L (2006) Functional characterization of homoand heteromeric channel kinases TRPM6 and TRPM7. J Gen Physiol 127(5):525-537

119. Liedtke W, Choe Y, Martí-Renom MA, Bell AM, Denis CS, Sali A, Hudspeth AJ, Friedman JM, Heller S (2000) Vanilloid receptor-related osmotically activated channel (VROAC), a candidate vertebrate osmoreceptor. Cell 103(3):525535

120. Lièvremont J-P, Bird GSJ, Putney JW Jr (2004) Canonical transient receptor potential TRPC7 can function as both a receptor- and storeoperated channel in HEK-293 cells. Am J Physiol Cell Physiol 287(6):C1709-C1716

121. Lis A, Wissenbach U, Philipp SE (2005) Transcriptional regulation and processing increase the functional variability of TRPM channels. Naunyn-Schmiedeberg's Arch Pharmacol 371(4):315-324

122. Löf C, Blom T, Törnquist K (2008) Overexpression of TRPC3 reduces the content of intracellular calcium stores in HEK-293 cells. J Cell Physiol 216(1):245-252

123. LopezJimenez ND, Cavenagh MM, Sainz E, Cruz-Ithier MA, Battey JF, Sullivan SL (2006) Two members of the TRPP family of ion channels, Pkd113 and Pkd211, are co-expressed in a subset of taste receptor cells. J Neurochem 98(1):68-77

124. Luebbert M, Radtke D, Wodarski R, Damann N, Hatt H, Wetzel CH (2010) Direct activation of transient receptor potential V1 by nickel ions. Pflugers Arch 459(5):737-750

125. Luo J, Stewart R, Berdeaux R, Hu H (2012) Tonic inhibition of TRPV3 by $\mathrm{Mg}^{2+}$ in mouse epidermal keratinocytes. J Invest Dermatol 132(9):2158-2165

126. Martineau C, Abed E, Médina G, Jomphe L-A, Mantha M, Jumarie C, Moreau R (2010) Involvement of transient receptor potential melastatin-related 7 (TRPM7) channels in cadmium uptake and cytotoxicity in MC3T3-E1 osteoblasts. Toxicol Lett 199(3): 357-363

127. Mayer ML, Westbrook GL (1987) Permeation and block of Nmethyl-D-aspartic acid receptor channels by divalent cations in mouse cultured central neurones. J Physiol 394:501-527

128. McHugh D, Flemming R, Xu S-Z, Perraud A-L, Beech DJ (2003) Critical intracellular $\mathrm{Ca}^{2+}$ dependence of transient receptor potential melastatin 2 (TRPM2) cation channel activation. J Biol Chem 278(13):11002-11006

129. McKay RR, Szymeczek-Seay CL, Lievremont JP, Bird GS, Zitt C, Jüngling E, Lückhoff A, Putney J Jr (2000) Cloning and expression of the human transient receptor potential 4 (TRP4) gene: localization and functional expression of human TRP4 and TRP3. Biochem J 351(Pt 3):735-746

130. McKemy DD, Neuhausser WM, Julius D (2002) Identification of a cold receptor reveals a general role for TRP channels in thermosensation. Nature 416(6876):52-58

131. Mederos y Schnitzler M, Wäring J, Gudermann T, Chubanov V (2008) Evolutionary determinants of divergent calcium selectivity of TRPM channels. FASEB J 22(5):1540-1551

132. Medina DL, Fraldi A, Bouche V, Annunziata F, Mansueto G, Spampanato C, Puri C, Pignata A, Martina JA, Sardiello M,
Palmieri M, Polishchuk R, Puertollano R, Ballabio A (2011) Transcriptional activation of lysosomal exocytosis promotes cellular clearance. Dev Cell 21(3):421-430

133. Mergler S, Mertens C, Valtink M, Reinach PS, Castelo Székely V, Slavi N, Garreis F, Abdelmessih S, Türker E, Fels G, Pleyer U (2013) Functional significance of thermosensitive transient receptor potential melastatin channel 8 (TRPM8) expression in immortalized human corneal endothelial cells. Exp Eye Res 116:337-349

134. Meyers JR, MacDonald RB, Duggan A, Lenzi D, Standaert DG, Corwin JT, Corey DP (2003) Lighting up the senses: FM1-43 loading of sensory cells through nonselective ion channels. J Neurosci 23(10):4054-4065

135. Min K-S, Ueda H, Tanaka K (2008) Involvement of intestinal calcium transporter 1 and metallothionein in cadmium accumulation in the liver and kidney of mice fed a low-calcium diet. Toxicol Lett 176(1):85-92

136. Miura S, Takahashi K, Imagawa T, Uchida K, Saito S, Tominaga M, Ohta T (2013) Involvement of TRPA1 activation in acute pain induced by cadmium in mice. Mol Pain 9:7

137. Monteilh-Zoller MK, Hermosura MC, Nadler MJS, Scharenberg AM, Penner R, Fleig A (2003) TRPM7 provides an ion channel mechanism for cellular entry of trace metal ions. J Gen Physiol 121(1):49-60

138. Morgans CW, Brown RL, Duvoisin RM (2010) TRPM1: the endpoint of the mGluR6 signal transduction cascade in retinal ONbipolar cells. Bioessays 32(7):609-614

139. Morita H, Honda A, Inoue R, Ito Y, Abe K, Nelson MT, Brayden JE (2007) Membrane stretch-induced activation of a TRPM4-like nonselective cation channel in cerebral artery myocytes. J Pharmacol Sci 103(4):417-426

140. Mukherjea D, Jajoo S, Kaur T, Sheehan KE, Ramkumar V, Rybak LP (2010) Transtympanic administration of short interfering (si)RNA for the NOX3 isoform of NADPH oxidase protects against cisplatin-induced hearing loss in the rat. Antioxid Redox Signal 13(5):589-598

141. Mukherjea D, Jajoo S, Sheehan K, Kaur T, Sheth S, Bunch J, Perro C, Rybak LP, Ramkumar V (2011) NOX3 NADPH oxidase couples transient receptor potential vanilloid 1 to signal transducer and activator of transcription 1-mediated inflammation and hearing loss. Antioxid Redox Signal 14(6):999-1010

142. Mukherjea D, Jajoo S, Whitworth C, Bunch JR, Turner JG, Rybak LP, Ramkumar V (2008) Short interfering RNA against transient receptor potential vanilloid 1 attenuates cisplatin-induced hearing loss in the rat. J Neurosci 28(49):13056-13065

143. Mwanjewe J, Grover AK (2004) Role of transient receptor potential canonical 6 (TRPC6) in non-transferrin-bound iron uptake in neuronal phenotype PC12 cells. Biochem J 378(Pt 3):975-982

144. Nadler MJ, Hermosura MC, Inabe K, Perraud AL, Zhu Q, Stokes AJ, Kurosaki T, Kinet JP, Penner R, Scharenberg AM, Fleig A (2001) LTRPC7 is a Mg.ATP-regulated divalent cation channel required for cell viability. Nature 411(6837):590-595

145. Nagata K, Duggan A, Kumar G, García-Añoveros J (2005) Nociceptor and hair cell transducer properties of TRPA1, a channel for pain and hearing. J Neurosci 25(16):4052-4061

146. Nagata K, Zheng L, Madathany T, Castiglioni AJ, Bartles JR, García-Añoveros J (2008) The varitint-waddler (Va) deafness mutation in TRPML3 generates constitutive, inward rectifying currents and causes cell degeneration. Proc Natl Acad Sci U S A 105(1): 353-358

147. Nagy I, Pabla R, Matesz C, Dray A, Woolf CJ, Urban L (1993) Cobalt uptake enables identification of capsaicin- and bradykininsensitive subpopulations of rat dorsal root ganglion cells in vitro. Neuroscience 56(1):241-246

148. Nassini R, Gees M, Harrison S, De Siena G, Materazzi S, Moretto N, Failli P, Preti D, Marchetti N, Cavazzini A, Mancini F, Pedretti P, 
Nilius B, Patacchini R, Geppetti P (2011) Oxaliplatin elicits mechanical and cold allodynia in rodents via TRPA1 receptor stimulation. Pain 152(7):1621-1631

149. Nativi C, Gualdani R, Dragoni E, Di Cesare Mannelli L, Sostegni S, Norcini M, Gabrielli G, la Marca G, Richichi B, Francesconi O, Moncelli MR, Ghelardini C, Roelens S (2013) A TRPA1 antagonist reverts oxaliplatin-induced neuropathic pain. Sci Rep 3:2005

150. Naylor J, Li J, Milligan CJ, Zeng F, Sukumar P, Hou B, Sedo A, Yuldasheva N, Majeed Y, Beri D, Jiang S, Seymour VAL, McKeown L, Kumar B, Harteneck C, O'Regan D, Wheatcroft SB, Kearney MT, Jones C, Porter KE et al (2010) Pregnenolone sulphate- and cholesterol-regulated TRPM3 channels coupled to vascular smooth muscle secretion and contraction. Circ Res 106(9):1507-1515

151. Nelson TM, Lopezjimenez ND, Tessarollo L, Inoue M, Bachmanov AA, Sullivan SL (2010) Taste function in mice with a targeted mutation of the pkd113 gene. Chem Senses 35(7):565-577

152. Niemeyer BA, Suzuki E, Scott K, Jalink K, Zuker CS (1996) The Drosophila light-activated conductance is composed of the two channels TRP and TRPL. Cell 85(5):651-659

153. Nilius B, Appendino G, Owsianik G (2012) The transient receptor potential channel TRPA1: from gene to pathophysiology. Pflugers Arch 464(5):425-458

154. Nilius B, Owsianik G (2011) The transient receptor potential family of ion channels. Genome Biol 12(3):218

155. Nilius B, Prenen J, Droogmans G, Voets T, Vennekens R, Freichel M, Wissenbach U, Flockerzi V (2003) Voltage dependence of the $\mathrm{Ca}^{2+}$-activated cation channel TRPM4. J Biol Chem 278(33): 30813-30820

156. Oancea E, Vriens J, Brauchi S, Jun J, Splawski I, Clapham DE (2009) TRPM1 forms ion channels associated with melanin content in melanocytes. Sci Signal 2(70):ra21

157. Oberwinkler J, Lis A, Giehl KM, Flockerzi V, Philipp SE (2005) Alternative splicing switches the divalent cation selectivity of TRPM3 channels. J Biol Chem 280(23):22540 22548

158. Oberwinkler J, Philipp SE (2007) TRPM3. Handb Exp Pharmacol 179:253-267

159. Obukhov AG, Nowycky MC (2005) A cytosolic residue mediates $\mathrm{Mg} 2+$ block and regulates inward current amplitude of a transient receptor potential channel. J Neurosci 25(5):1234-1239

160. Okada $\mathrm{T}$, Inoue $\mathrm{R}$, Yamazaki $\mathrm{K}$, Maeda A, Kurosaki $\mathrm{T}$, Yamakuni T, Tanaka I, Shimizu S, Ikenaka K, Imoto K, Mori Y (1999) Molecular and functional characterization of a novel mouse transient receptor potential protein homologue TRP7. $\mathrm{Ca}(2+)$-permeable cation channel that is constitutively activated and enhanced by stimulation of $\mathrm{G}$ protein-coupled receptor. J Biol Chem 274(39):27359-27370

161. Oudit GY, Sun H, Trivieri MG, Koch SE, Dawood F, Ackerley C, Yazdanpanah M, Wilson GJ, Schwartz A, Liu PP, Backx PH (2003) L-type $\mathrm{Ca}^{2+}$ channels provide a major pathway for iron entry into cardiomyocytes in iron-overload cardiomyopathy. Nat Med 9(9): $1187-1194$

162. Patapoutian A, Peier AM, Story GM, Viswanath V (2003) ThermoTRP channels and beyond: mechanisms of temperature sensation. Nat Rev Neurosci 4(7):529-539

163. Peng JB, Chen XZ, Berger UV, Vassilev PM, Tsukaguchi H, Brown EM, Hediger MA (1999) Molecular cloning and characterization of a channel-like transporter mediating intestinal calcium absorption. J Biol Chem 274(32):22739-22746

164. Peng JB, Chen XZ, Berger UV, Weremowicz S, Morton CC, Vassilev PM, Brown EM, Hediger MA (2000) Human calcium transport protein CaT1. Biochem Biophys Res Commun 278(2): 326-332

165. Penner R, Fleig A (2007) The $\mathrm{Mg}^{2+}$ and $\mathrm{Mg}^{2+}$-nucleotide-regulated channel-kinase TRPM7. Handb Exp Pharmacol 179:313-328
166. Pérez CA, Huang L, Rong M, Kozak JA, Preuss AK, Zhang H, Max M, Margolskee RF (2002) A transient receptor potential channel expressed in taste receptor cells. Nat Neurosci 5(11):1169-1176

167. Perraud AL, Fleig A, Dunn CA, Bagley LA, Launay P, Schmitz C, Stokes AJ, Zhu Q, Bessman MJ, Penner R, Kinet JP, Scharenberg AM (2001) ADP-ribose gating of the calcium-permeable LTRPC2 channel revealed by Nudix motif homology. Nature 411(6837): 595-599

168. Prakriya M, Lewis RS (2002) Separation and characterization of currents through store-operated CRAC channels and $\mathrm{Mg}^{2+}$. inhibited cation (MIC) channels. J Gen Physiol 119(5):487-507

169. Puertollano R, Kiselyov K (2009) TRPMLs: in sickness and in health. Am J Physiol Renal Physiol 296(6):F1245-F1254

170. Rampino MAF, Nawy SA (2011) Relief of $\mathrm{Mg}^{2+}$-dependent inhibition of TRPM1 by PKC $\alpha$ at the rod bipolar cell synapse. J Neurosci 31(38):13596-13603

171. Ramsey IS, Delling M, Clapham DE (2006) An introduction to TRP channels. Annu Rev Physiol 68:619-647

172. Reuss H, Mojet MH, Chyb S, Hardie RC (1997) In vivo analysis of the Drosophila light-sensitive channels, TRP and TRPL. Neuron 19(6):1249-1259

173. Riccio A, Mattei C, Kelsell RE, Medhurst AD, Calver AR, Randall AD, Davis JB, Benham CD, Pangalos MN (2002) Cloning and functional expression of human short TRP7, a candidate protein for store-operated $\mathrm{Ca}^{2+}$ influx. J Biol Chem 277(14):12302-12309

174. Riera CE, Vogel H, Simon SA, Damak S, le Coutre J (2009) Sensory attributes of complex tasting divalent salts are mediated by TRPM5 and TRPV1 channels. J Neurosci 29(8):2654-2662

175. Rohács T, Lopes CMB, Michailidis I, Logothetis DE (2005) PI(4, 5)P2 regulates the activation and desensitization of TRPM 8 channels through the TRP domain. Nat Neurosci 8(5):626-634

176. Runnels LW, Yue L, Clapham DE (2001) TRP-PLIK, a bifunctional protein with kinase and ion channel activities. Science 291(5506): 1043-1047

177. Ryazanova LV, Pavur KS, Petrov AN, Dorovkov MV, Ryazanov AG (2001) Novel type of signaling molecules: protein kinases covalently linked with ion channels. Mol Biol 35(2):271-283

178. Ryazanova LV, Rondon LJ, Zierler S, Hu Z, Galli J, Yamaguchi TP, Mazur A, Fleig A, Ryazanov AG (2010) TRPM7 is essential for $\mathrm{Mg}(2+)$ homeostasis in mammals. Nat Commun 1:109

179. Samie M, Wang X, Zhang X, Goschka A, Li X, Cheng X, Gregg E, Azar M, Zhuo Y, Garrity AG, Gao Q, Slaugenhaupt S, Pickel J, Zolov SN, Weisman LS, Lenk GM, Titus S, Bryant-Genevier M, Southall N, Juan M et al (2013) A TRP channel in the lysosome regulates large particle phagocytosis via focal exocytosis. Dev Cell 26(5):511-524

180. Sathianathan V, Avelino A, Charrua A, Santha P, Matesz K, Cruz F, Nagy I (2003) Insulin induces cobalt uptake in a subpopulation of rat cultured primary sensory neurons. Eur J Neurosci 18(9):2477-2486

181. Schaefer M, Plant TD, Obukhov AG, Hofmann T, Gudermann T, Schultz G (2000) Receptor-mediated regulation of the nonselective cation channels TRPC4 and TRPC5. J Biol Chem 275(23):1751717526

182. Schlingmann KP, Waldegger S, Konrad M, Chubanov V, Gudermann T (2007) TRPM6 and TRPM7-Gatekeepers of human magnesium metabolism. Biochim Biophys Acta 1772(8):813-821

183. Schmitz C, Perraud A-L, Johnson CO, Inabe K, Smith MK, Penner R, Kurosaki T, Fleig A, Scharenberg AM (2003) Regulation of vertebrate cellular $\mathrm{Mg}^{2+}$ homeostasis by TRPM7. Cell 114(2): 191-200

184. Schou M (2001) Lithium treatment at 52. J Affect Disord 67(1-3): 21-32

185. Scotland RS, Chauhan S, Davis C, De Felipe C, Hunt S, Kabir J, Kotsonis P, Oh U, Ahluwalia A (2004) Vanilloid receptor TRPV1, sensory C-fibers, and vascular autoregulation: a novel mechanism involved in myogenic constriction. Circ Res 95(10):1027-1034 
186. Semtner M, Schaefer M, Pinkenburg O, Plant TD (2007) Potentiation of TRPC5 by protons. J Biol Chem 282(46):3386833878

187. Sinkins WG, Estacion M, Schilling WP (1998) Functional expression of TrpC1: a human homologue of the Drosophila Trp channel. Biochem J 331(Pt 1):331-339

188. Starkus J, Beck A, Fleig A, Penner R (2007) Regulation of TRPM2 by extra- and intracellular calcium. J Gen Physiol 130(4):427-440

189. Straub I, Krügel U, Mohr F, Teichert J, Rizun O, Konrad M, Oberwinkler J, Schaefer M (2013) Flavanones that selectively inhibit TRPM3 attenuate thermal nociception in vivo. Mol Pharmacol 84(5):736-750

190. Strotmann R, Harteneck C, Nunnenmacher K, Schultz G, Plant TD (2000) OTRPC4, a nonselective cation channel that confers sensitivity to extracellular osmolarity. Nat Cell Biol 2(10):695-702

191. Strotmann R, Schultz G, Plant TD (2003) $\mathrm{Ca}^{2+}$-dependent potentiation of the nonselective cation channel TRPV4 is mediated by a Cterminal calmodulin binding site. J Biol Chem 278(29):2654126549

192. Strübing C, Krapivinsky G, Krapivinsky L, Clapham DE (2001) TRPC1 and TRPC5 form a novel cation channel in mammalian brain. Neuron 29(3):645-655

193. Su L-T, Agapito MA, Li M, Simonson WTN, Huttenlocher A, Habas R, Yue L, Runnels LW (2006) TRPM7 regulates cell adhesion by controlling the calcium-dependent protease calpain. J Biol Chem 281(16):11260-11270

194. Sukumar P, Beech DJ (2010) Stimulation of TRPC5 cationic channels by low micromolar concentrations of lead ions $\left(\mathrm{Pb}^{2+}\right)$. Biochem Biophys Res Commun 393(1):50-54

195. Sun M, Goldin E, Stahl S, Falardeau JL, Kennedy JC, Acierno J Jr, Bove C, Kaneski CR, Nagle J, Bromley MC, Colman M, Schiffmann R, Slaugenhaupt SA (2000) Mucolipidosis type IV is caused by mutations in a gene encoding a novel transient receptor potential channel. Hum Mol Genet 9(17):2471-2478

196. Sun Y-h, Li Y-q, Feng S-1, Li B-x, Pan Z-w, Xu C-q, Li T-t, Yang B-f (2010) Calcium-sensing receptor activation contributed to apoptosis stimulates TRPC6 channel in rat neonatal ventricular myocytes. Biochem Biophys Res Commun 394(4):955-961

197. Sutton KA, Jungnickel MK, Ward CJ, Harris PC, Florman HM (2006) Functional characterization of PKDREJ, a male germ cellrestricted polycystin. J Cell Physiol 209(2):493-500

198. Ta LE, Bieber AJ, Carlton SM, Loprinzi CL, Low PA, Windebank AJ (2010) Transient receptor potential vanilloid 1 is essential for cisplatin-induced heat hyperalgesia in mice. Mol Pain 6:15

199. Teramoto T, Lambie EJ, Iwasaki K (2005) Differential regulation of TRPM channels governs electrolyte homeostasis in the C. elegans intestine. Cell Metab 1(5):343-354

200. Teramoto T, Sternick LA, Kage-Nakadai E, Sajjadi S, Siembida J, Mitani S, Iwasaki K, Lambie EJ (2010) Magnesium excretion in C. elegans requires the activity of the GTL-2 TRPM channel. PLoS One 5(3): e9589

201. Tesfai Y, Brereton HM, Barritt GJ (2001) A diacylglycerol-activated $\mathrm{Ca}^{2+}$ channel in PC12 cells (an adrenal chromaffin cell line) correlates with expression of the TRP-6 (transient receptor potential) protein. Biochem J 358(Pt 3):717-726

202. Thebault S, Lemonnier L, Bidaux G, Flourakis M, Bavencoffe A, Gordienko D, Roudbaraki M, Delcourt P, Panchin Y, Shuba Y, Skryma R, Prevarskaya N (2005) Novel role of cold/menthol-sensitive transient receptor potential melastatine family member 8 (TRPM8) in the activation of store-operated channels in LNCaP human prostate cancer epithelial cells. J Biol Chem 280(47):3942339435

203. Togashi K, Hara Y, Tominaga T, Higashi T, Konishi Y, Mori Y, Tominaga M (2006) TRPM2 activation by cyclic ADP-ribose at body temperature is involved in insulin secretion. EMBO J 25(9): 1804-1815

204. Topala CN, Groenestege WT, Thébault S, van den Berg D, Nilius B, Hoenderop JG, Bindels RJ (2007) Molecular determinants of permeation through the cation channel TRPM6. Cell Calcium 41(6): 513-523

205. Tóth B, Csanády L (2012) Pore collapse underlies irreversible inactivation of TRPM2 cation channel currents. Proc Natl Acad Sci U S A 109(33):13440-13445

206. Tousova K, Susankova K, Teisinger J, Vyklicky L, Vlachova V (2004) Oxidizing reagent copper-o-phenanthroline is an open channel blocker of the vanilloid receptor TRPV1. Neuropharmacology 47(2):273-285

207. Tousova K, Vyklicky L, Susankova K, Benedikt J, Vlachova V (2005) Gadolinium activates and sensitizes the vanilloid receptor TRPV1 through the external protonation sites. Mol Cell Neurosci 30(2):207-217

208. Tsiokas L, Kim E, Arnould T, Sukhatme VP, Walz G (1997) Homo- and heterodimeric interactions between the gene products of PKD1 and PKD2. Proc Natl Acad Sci U S A 94(13):69656970

209. Uchida K, Tominaga M (2013) Extracellular zinc ion regulates transient receptor potential melastatin 5 (TRPM5) channel activation through its interaction with a pore loop domain. J Biol Chem 288(36):25950-25955

210. Vanden Abeele F, Zholos A, Bidaux G, Shuba Y, Thebault S, Beck B, Flourakis M, Panchin Y, Skryma R, Prevarskaya N (2006) $\mathrm{Ca}^{2+}$-independent phospholipase A2-dependent gating of TRPM8 by lysophospholipids. J Biol Chem 281(52): 40174-40182

211. Vazquez G, Lievremont JP, St J, Bird G, Putney J Jr (2001) Human Trp3 forms both inositol trisphosphate receptor-dependent and receptor-independent store-operated cation channels in DT40 avian B lymphocytes. Proc Natl Acad Sci U S A 98(20):11777-11782

212. Venkatachalam K, Montell C (2007) TRP Channels. Annu Rev Biochem 76:387-417

213. Vennekens R, Hoenderop JG, Prenen J, Stuiver M, Willems PH, Droogmans G, Nilius B, Bindels RJ (2000) Permeation and gating properties of the novel epithelial $\mathrm{Ca}^{2+}$ channel. J Biol Chem 275(6): 3963-3969

214. Vennekens R, Nilius B (2007) Insights into TRPM4 function, regulation and physiological role. Handb Exp Pharmacol 179: 269-285

215. Vennekens R, Prenen J, Hoenderop JG, Bindels RJ, Droogmans G, Nilius B (2001) Pore properties and ionic block of the rabbit epithelial calcium channel expressed in HEK 293 cells. J Physiol 530(Pt 2):183-191

216. Voets T, Janssens A, Prenen J, Droogmans G, Nilius B (2003) $\mathrm{Mg}^{2+}$-dependent gating and strong inward rectification of the cation channel TRPV6. J Gen Physiol 121(3):245-260

217. Voets T, Nilius B, Hoefs S, van der Kemp AWCM, Droogmans G, Bindels RJM, Hoenderop JGJ (2004) TRPM6 forms the $\mathrm{Mg}^{2+}$ influx channel involved in intestinal and renal $\mathrm{Mg}^{2+}$ absorption. $\mathrm{J}$ Biol Chem 279(1):19-25

218. Voets T, Prenen J, Fleig A, Vennekens R, Watanabe H, Hoenderop JG, Bindels RJ, Droogmans G, Penner R, Nilius B (2001) CaT1 and the calcium release-activated calcium channel manifest distinct pore properties. J Biol Chem 276(51):47767-47770

219. Voets T, Prenen J, Vriens J, Watanabe H, Janssens A, Wissenbach U, Bödding M, Droogmans G, Nilius B (2002) Molecular determinants of permeation through the cation channel TRPV4. J Biol Chem 277(37):33704-33710

220. Vriens J, Held K, Janssens A, Tóth BI, Kerselaers S, Nilius B, Vennekens R, Voets T (2014) Opening of an alternative ion permeation pathway in a nociceptor TRP channel. Nat Chem Biol 10(3): 188-195 
221. Vriens J, Owsianik G, Hofmann T, Philipp SE, Stab J, Chen X, Benoit M, Xue F, Janssens A, Kerselaers S, Oberwinkler J, Vennekens R, Gudermann T, Nilius B, Voets T (2011) TRPM3 is a nociceptor channel involved in the detection of noxious heat. Neuron 70(3):482-494

222. Wagner TFJ, Drews A, Loch S, Mohr F, Philipp SE, Lambert S, Oberwinkler J (2010) TRPM3 channels provide a regulated influx pathway for zinc in pancreatic beta cells. Pflugers Arch 460:755-765

223. Wagner TFJ, Loch S, Lambert S, Straub I, Mannebach S, Mathar I, Düfer M, Lis A, Flockerzi V, Philipp SE, Oberwinkler J (2008) Transient receptor potential M3 channels are ionotropic steroid receptors in pancreatic $\beta$ cells. Nat Cell Biol 10(12):1421-1430

224. Walder RY, Landau D, Meyer P, Shalev H, Tsolia M, Borochowitz Z, Boettger MB, Beck GE, Englehardt RK, Carmi R, Sheffield VC (2002) Mutation of TRPM6 causes familial hypomagnesemia with secondary hypocalcemia. Nat Genet 31(2):171-174

225. Wang D, Lippard SJ (2005) Cellular processing of platinum anticancer drugs. Nat Rev Drug Discov 4(4):307-320

226. Wang S, Poon K, Oswald RE, Chuang H-h (2010) Distinct modulations of human capsaicin receptor by protons and magnesium through different domains. J Biol Chem 285(15):11547-11556

227. Wang YY, Chang RB, Waters HN, McKemy DD, Liman ER (2008) The nociceptor ion channel TRPA1 is potentiated and inactivated by permeating calcium ions. J Biol Chem 283(47):32691-32703

228. Wissenbach U, Bödding M, Freichel M, Flockerzi V (2000) Trp12, a novel Trp related protein from kidney. FEBS Lett 485(23): $127-134$

229. Wissenbach U, Niemeyer BA, Fixemer T, Schneidewind A, Trost C, Cavalie A, Reus K, Meese E, Bonkhoff H, Flockerzi V (2001) Expression of CaT-like, a novel calcium-selective channel, correlates with the malignancy of prostate cancer. J Biol Chem 276(22): 19461-19468

230. Wolf FI, Trapani V (2008) Cell (patho)physiology of magnesium. Clin Sci (Lond) 114(1):27-35

231. Xia R, Mei Z-Z, Mao H-J, Yang W, Dong L, Bradley H, Beech DJ, Jiang L-H (2008) Identification of pore residues engaged in determining divalent cationic permeation in transient receptor potential melastatin subtype channel 2. J Biol Chem 283(41):27426-27432

232. Xing J, Yan X, Estevez A, Strange K (2008) Highly $\mathrm{Ca}^{2+}$ selective TRPM channels regulate $\mathrm{IP}_{3}$-dependent oscillatory $\mathrm{Ca}^{2+}$ signaling in the $\mathrm{C}$. elegans intestine. J Gen Physiol 131(3):245-255

233. Xu H, Delling M, Li L, Dong X, Clapham DE (2007) Activating mutation in a mucolipin transient receptor potential channel leads to melanocyte loss in varitint-waddler mice. Proc Natl Acad Sci U S A 104(46):18321-18326
234. Xu S-Z, Sukumar P, Zeng F, Li J, Jairaman A, English A, Naylor J, Ciurtin C, Majeed Y, Milligan CJ, Bahnasi YM, Al-Shawaf E, Porter KE, Jiang L-H, Emery P, Sivaprasadarao A, Beech DJ (2008) TRPC channel activation by extracellular thioredoxin. Nature 451(7174):69-72

235. Xu S-Z, Zeng B, Daskoulidou N, Chen G-L, Atkin SL, Lukhele B (2012) Activation of TRPC cationic channels by mercurial compounds confers the cytotoxicity of mercury exposure. Toxicol Sci 125(1):56-68

236. Xu XZ, Moebius F, Gill DL, Montell C (2001) Regulation of melastatin, a TRP-related protein, through interaction with a cytoplasmic isoform. Proc Natl Acad Sci U S A 98(19):10692-10697

237. Yang F, Cui Y, Wang K, Zheng J (2010) Thermosensitive TRP channel pore turret is part of the temperature activation pathway. Proc Natl Acad Sci U S A 107(15):7083-7088

238. Yang F, Ma L, Cao X, Wang K, Zheng J (2014) Divalent cations activate TRPV1 through promoting conformational change of the extracellular region. J Gen Physiol 143(1):91-103

239. Yang W, Manna PT, Zou J, Luo J, Beech DJ, Sivaprasadarao A, Jiang L-H (2011) Zinc inactivates melastatin transient receptor potential 2 channels via the outer pore. J Biol Chem 286(27): 23789-23798

240. Yu Y, Ulbrich MH, Li M-H, Dobbins S, Zhang WK, Tong L, Isacoff EY, Yang J (2012) Molecular mechanism of the assembly of an acid-sensing receptor ion channel complex. Nat Commun 3:1252

241. Yue L, Peng JB, Hediger MA, Clapham DE (2001) CaT1 manifests the pore properties of the calcium-release-activated calcium channel. Nature 410(6829):705-709

242. Zeevi DA, Frumkin A, Bach G (2007) TRPML and lysosomal function. Biochim Biophys Acta 1772(8):851-858

243. Zeng F, Xu S-Z, Jackson PK, McHugh D, Kumar B, Fountain SJ, Beech DJ (2004) Human TRPC5 channel activated by a multiplicity of signals in a single cell. J Physiol 559(Pt 3):739-750

244. Zhao M, Isami K, Nakamura S, Shirakawa H, Nakagawa T, Kaneko S (2012) Acute cold hypersensitivity characteristically induced by oxaliplatin is caused by the enhanced responsiveness of TRPA1 in mice. Mol Pain 8:55

245. Zhu X, Jiang M, Birnbaumer L (1998) Receptor-activated $\mathrm{Ca}^{2+}$ influx via human Trp3 stably expressed in human embryonic kidney (HEK) 293 cells. Evidence for a non-capacitative $\mathrm{Ca}^{2+}$ entry. J Biol Chem 273(1):133-142

246. Zhu X, Jiang M, Peyton M, Boulay G, Hurst R, Stefani E, Birnbaumer L (1996) trp, a novel mammalian gene family essential for agonist-activated capacitative $\mathrm{Ca}^{2+}$ entry. Cell 85(5):661-671

247. Zitt C, Zobel A, Obukhov AG, Harteneck C, Kalkbrenner F, Lückhoff A, Schultz G (1996) Cloning and functional expression of a human $\mathrm{Ca}^{2+}$-permeable cation channel activated by calcium store depletion. Neuron 16(6):1189-1196 